University of Nebraska - Lincoln

DigitalCommons@University of Nebraska - Lincoln

USDA Forest Service / UNL Faculty Publications U.S. Department of Agriculture: Forest Service -National Agroforestry Center

2012

\title{
Seasonal dynamics and age of stemwood nonstructural carbohydrates in temperate forest trees
}

\author{
Andrew D. Richardson \\ Harvard University, arichardson@oeb.harvard.edu \\ Mariah S. Carbone \\ National Center for Ecological Analysis and Synthesis, mcarbone@nceas.ucsb.edu \\ Trevor F. Keenan \\ Harvard University \\ Claudia I. Czimczik \\ University of California - Irvine, czimczik@uci.edu \\ David Y. Hollinger \\ USDA Forest Service, davidh@hypatia.unh.edu \\ See next page for additional authors
}

Follow this and additional works at: https://digitalcommons.unl.edu/usdafsfacpub

Richardson, Andrew D.; Carbone, Mariah S.; Keenan, Trevor F.; Czimczik, Claudia I.; Hollinger, David Y.; Murakami, Paula; Schaberg, Paul G.; and Xu, Xiaomei, "Seasonal dynamics and age of stemwood nonstructural carbohydrates in temperate forest trees" (2012). USDA Forest Service / UNL Faculty Publications. 230.

https://digitalcommons.unl.edu/usdafsfacpub/230

This Article is brought to you for free and open access by the U.S. Department of Agriculture: Forest Service -National Agroforestry Center at DigitalCommons@University of Nebraska - Lincoln. It has been accepted for inclusion in USDA Forest Service / UNL Faculty Publications by an authorized administrator of DigitalCommons@University of Nebraska - Lincoln. 
Authors

Andrew D. Richardson, Mariah S. Carbone, Trevor F. Keenan, Claudia I. Czimczik, David Y. Hollinger, Paula Murakami, Paul G. Schaberg, and Xiaomei Xu 


\title{
Seasonal dynamics and age of stemwood nonstructural carbohydrates in temperate forest trees
}

\author{
Andrew D. Richardson ${ }^{1}$, Mariah S. Carbone ${ }^{2}$, Trevor F. Keenan ${ }^{1}$, Claudia I. Czimczik ${ }^{3}$, David Y. Hollinger ${ }^{4}$, \\ Paula Murakami ${ }^{5}$, Paul G. Schaberg ${ }^{5}$ and Xiaomei $\mathrm{Xu}^{3}$
}

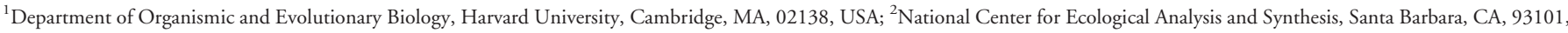

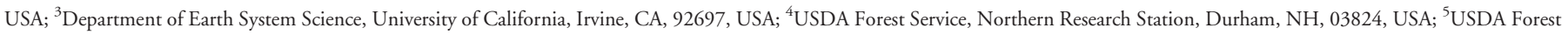
Service, Northern Research Station, Burlington, VT, 05403, USA

Author for correspondence:

Andrew D. Richardson

Tel: +16174961277

Email: arichardson@oeb.harvard.edu

Received: 27 June 2012

Accepted: 7 October 2012

New Phytologist (2012)

doi: $10.1111 /$ nph.12042

Key words: carbon allocation, carbon cycle model, mean residence time, nonstructural carbohydrate (NSC) reserves, radiocarbon $\left({ }^{14} \mathrm{C}\right)$, starch.

\section{Summary}

- Nonstructural carbohydrate reserves support tree metabolism and growth when current photosynthates are insufficient, offering resilience in times of stress.

- We monitored stemwood nonstructural carbohydrate (starch and sugars) concentrations of the dominant tree species at three sites in the northeastern United States. We estimated the mean age of the starch and sugars in a subset of trees using the radiocarbon $\left({ }^{14} \mathrm{C}\right)$ bomb spike. With these data, we then tested different carbon (C) allocation schemes in a process-based model of forest $C$ cycling.

- We found that the nonstructural carbohydrates are both highly dynamic and about a decade old. Seasonal dynamics in starch (two to four times higher in the growing season, lower in the dormant season) mirrored those of sugars. Radiocarbon-based estimates indicated that the mean age of the starch and sugars in red maple (Acer rubrum) was 7-14 yr.

- A two-pool (fast and slow cycling reserves) model structure gave reasonable estimates of the size and mean residence time of the total NSC pool, and greatly improved model predictions of interannual variability in woody biomass increment, compared with zero- or one-pool structures used in the majority of existing models. This highlights the importance of nonstructural carbohydrates in the context of forest ecosystem carbon cycling.

\section{Introduction}

Forest trees, like all plants, accumulate and store nonstructural carbohydrates (NSC) as resources to be used to support future growth and metabolism (Chapin et al., 1990). The NSC pool is the sum of soluble sugars, mainly sucrose, plus starch. The dynamics of NSCs are considered indicators of carbon (C) sourcesink relationships. Körner (2003) made the analogy that the size of a tree's NSC pool reflects its C 'fueling status'. Recent analyses (Barbaroux \& Breda, 2002; Gough et al., 2009) suggest that a large fraction of a tree's annual C budget is allocated to the NSC pool, and Würth et al. (2005) estimated the total NSC pool in a tropical forest ecosystem to be $8 \%$ of living biomass, which scales to $25 \mathrm{Pg} \mathrm{C}$ if this proportion holds globally.

Processes and pathways related to NSC allocation and storage could influence the impact of climate change on forest ecosystem $\mathrm{C}$ balance. However, $\mathrm{C}$ allocation processes remain poorly understood (Le Roux et al., 2001; Trumbore, 2006; Keel et al., 2007; Wiley \& Helliker, 2012), and many models treat allocation in an overly simplistic manner (Friedlingstein et al., 1999). Progress is hampered by the scarcity of field data necessary for model testing, with additional studies in mature natural forests in particular being needed (Barbaroux \& Breda, 2002; Hoch et al., 2003; Gough et al., 2009).

The standard conceptual model for NSCs is that the pool is: depleted when demand exceeds supply, for example, when metabolism and growth requirements are high, or when production of photoassimilates is limited by environmental conditions; and recharged when the supply exceeds demand, for example, when environmental conditions permit high rates of photosynthesis, or when metabolism and growth requirements are low (Chapin et al., 1990; Grulke et al., 2001; Gleason \& Ares, 2004) (cf. Körner's (2003) argument that the size of the NSC pool is primarily driven by demand-side factors). In this framework, storing NSCs for future use is viewed as a 'bet hedging' strategy, providing reserves that the tree can draw on in times of stress (Dunn et al., 1990; Kozlowski, 1992; Bond \& Midgley, 2001; Gleason \& Ares, 2004). Carbon isotope labeling studies have shown conclusively that stored NSCs are used to fuel growth and respiration when the supply of current photoassimilates is inadequate (Kagawa et al., 2006a; Keel et al., 2006, 2007; Carbone \& Trumbore, 2007; Kuptz etal., 2011). In addition, there is mounting evidence that stored NSCs, particularly in belowground organs, are still accessible a decade after assimilation 
(Schuur \& Trumbore, 2006; Vargas et al., 2009; Carbone et al., 2011).

The NSC pool may also play an important role in ecosystem $\mathrm{C}$ cycling. For example, at the Howland Forest AmeriFlux site the mean ( \pm 1 SD, 1996-2005) annual rate of net ecosystem exchange (NEE) of $\mathrm{CO}_{2}, \quad 185 \pm 47 \mathrm{~g} \mathrm{C} \mathrm{m}^{-2} \mathrm{yr}^{-1}$, is in substantial agreement with the mean annual rate of live tree biomass increment, $163 \pm 15 \mathrm{~g} \mathrm{C} \mathrm{m}^{-2} \mathrm{yr}^{-1}$ (Fig. 1). While there is no correlation between year-to-year fluctuations of the two timeseries $(r=0.07, P=0.85)$, there is a strong correlation between $\mathrm{NEE}$ in one year and biomass increment in the following year $\left(n_{\mathrm{ag}}=0.80, P<0.01\right)$. As hypothesized previously (Arneth et al., 1998; Kagawa etal., 2006b; Rocha et al., 2006; Navarro et al., 2008; Gough et al., 2009; Rocha \& Goulden, 2009), time lags between $\mathrm{C}$ uptake and biomass growth could be explained by a dynamic NSC pool that functions as temporary storage, with accumulated NSC not being drawn upon for allocation to growth until the following year.

We present the results of a multi-year (2007-2010) study of NSC dynamics in temperate forest trees. At quarterly intervals, we measured stemwood NSC concentrations in the dominant tree species at three sites in the northeastern USA. Our objectives were to:

- assess the seasonal dynamics and interannual variability in stemwood NSC (starch and sugars) concentrations, and evaluate whether these vary among species or across sites;

- quantify the mean age of stemwood starch and sugars, using the radiocarbon $\left({ }^{14} \mathrm{C}\right)$ bomb spike method;

- compare different approaches (no-, one- and two-pool NSC representations) to modeling $\mathrm{C}$ allocation and NSC dynamics in a parsimonious forest ecosystem $\mathrm{C}$ cycling model (Keenan et al., 2012). We use Howland Forest as a case study, in order to investigate our hypothesis for the lag observed in Fig. 1.

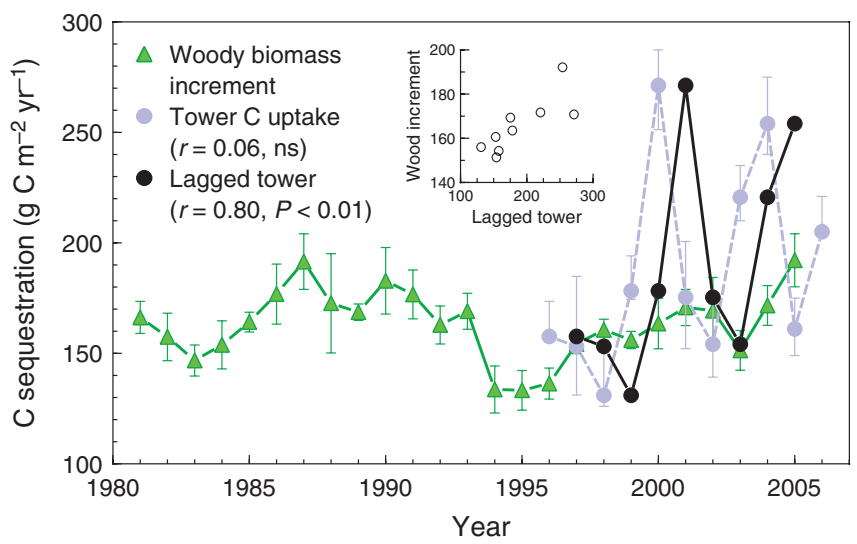

Fig. 1 Comparison of carbon (C) sequestration estimates for the Howland Forest AmeriFlux site, based on (1) measurements of woody biomass increment estimated from tree rings (see Richardson et al. 2010) and (2) tower measurements of net ecosystem exchange (NEE) of $\mathrm{CO}_{2}$ measured by eddy covariance ('tower $C$ uptake'; see Hollinger et al. 2004). The correlation between woody biomass increment and current-year tower $\mathrm{C}$ uptake is not statistically significant $(r=0.06, P=0.85)$, but woody biomass increment is well correlated with tower $C$ uptake in the previous year $(r=0.80, P<0.01)$, as shown in the inset plot.

\section{Materials and Methods}

\section{Study sites}

Field research was conducted at three sites in the northeastern USA: Howland Forest, Bartlett Experimental Forest, and Harvard Forest (Table 1). Monthly and annual departures from the longer-term (2001-2010) climatological means indicate substantial regional coherence for air temperature, but not solar radiation or precipitation, anomalies (see Supporting Information Fig. S1).

\section{Field sampling for NSC analyses}

In May 2007, transects were established in the AmeriFlux tower footprint at each site, and 60 trees (20 trees for each of three dominant species at each site; Table 2) were tagged and measured. We sought out healthy, dominant or codominant individuals of $\geq 25 \mathrm{~cm} \mathrm{DBH} \mathrm{(diameter} \mathrm{at} \mathrm{breast} \mathrm{height,} 1.3 \mathrm{~m}$ ), although in a small fraction of cases (17/180 trees), it was necessary to relax the minimum diameter requirement to $20 \mathrm{~cm}$.

At quarterly intervals (June, August, November and March), one-half of the trees of each species at each site were cored at breast height, on the south side of the trunk, to a depth of $3 \mathrm{~cm}$ with a standard $4.3 \mathrm{~mm}$ increment borer (Häglof Company Group, Långsele, Sweden). Each tree was cored six times over the 3 -yr course of measurements. Deciduous trees were in leaf during the June and August sampling dates, but were leafless in November and March. Cores were placed in clean plastic drinking straws (McDonald's Corporation, Oak Brook, IL, USA), labeled, and frozen in the field on dry ice.

Three additional sets of cores were collected:

- To investigate factors associated with the high rates of mortality observed for paper birch at Bartlett Experimental Forest, a subset of trees (20 paper birch, and 10 each of red maple and American beech) were cored to the pith for ring width measurements and age determination in Summer 2010. At the same time, we rated tree vigor according to Millers et al. (1991). These results are presented in the Supporting Information, Notes S2, Fig. S4;

- To investigate the mean ages of stemwood starch and sugars, two cores were collected from nine red maple at each site, and nine eastern hemlock at Howland Forest and Harvard Forest, in November 2010. The first of these cores was used for determination of NSC concentrations, while the second was used for radiocarbon (which we denote ${ }^{114} \mathrm{C}-\mathrm{NSC}$ ) analyses.

- To investigate relationships between tree age, the number of rings in the outer $2 \mathrm{~cm}$ of stemwood, and the age of starch and sugars, each of the nine ${ }^{14} \mathrm{C}-\mathrm{NSC}$ red maples at each site was cored to the pith for ring width measurements and age determination in Summer 2011.

\section{Concentrations of starch and sugars}

Analytical procedures for NSC determination followed Wong et al. (2003). Analysis was conducted only on the outer $2 \mathrm{~cm}$ of 
Table 1 Study sites where field sampling was conducted

\begin{tabular}{|c|c|c|c|c|c|}
\hline Site & Lat./Long. & Elev. $^{\mathrm{a}}$ & MAT/MAP & Vegetation & Reference \\
\hline $\begin{array}{l}\text { Howland Forest } \\
\text { (Maine) }\end{array}$ & $45.25^{\circ} \mathrm{N}, 68.73^{\circ} \mathrm{W}$ & $60 \mathrm{~m}$ & $6.7^{\circ} \mathrm{C}, 850 \mathrm{~mm}$ & Spruce-fir boreal transition & Hollinger et al. (2004) \\
\hline $\begin{array}{l}\text { Bartlett } \\
\text { Experimental } \\
\text { Forest (New } \\
\text { Hampshire) }\end{array}$ & $44.06^{\circ} \mathrm{N}, 71.29^{\circ} \mathrm{W}$ & $270 m$ & $7.3^{\circ} \mathrm{C}, 1270 \mathrm{~mm}$ & $\begin{array}{l}\text { Maple-beech-birch northern } \\
\text { hardwoods }\end{array}$ & Jenkins et al. (2007) \\
\hline $\begin{array}{l}\text { Harvard Forest } \\
\text { (Massachusetts) }\end{array}$ & $42.53^{\circ} \mathrm{N}, 72.17^{\circ} \mathrm{W}$ & $340 \mathrm{~m}$ & $8.2^{\circ} \mathrm{C}, 1270 \mathrm{~mm}$ & $\begin{array}{l}\text { Oak-dominated transition } \\
\text { hardwoods }\end{array}$ & Urbanski et al. (2007) \\
\hline
\end{tabular}

${ }^{a}$ Elevation in $\mathrm{m}$ ASL (above sea level).

${ }^{\mathrm{b}}$ MAT, mean annual temperature; MAP, mean annual precipitation, based on 2007-2010.

Table 2 Dimensions of trees sampled for stemwood nonstructural carbohydrate measurements

\begin{tabular}{|c|c|c|c|c|}
\hline \multirow[b]{2}{*}{ Site } & \multirow[b]{2}{*}{ Species } & \multicolumn{3}{|c|}{ Diameter at breast height $(\mathrm{cm})$} \\
\hline & & Mean \pm 1 SD & Minimum & Maximum \\
\hline \multirow[t]{3}{*}{ Howland Forest } & Red maple (Acer rubrum L.) & $28 \pm 7$ & 20 & 41 \\
\hline & Red spruce (Picea rubens Sarg.) & $31 \pm 7$ & 23 & 46 \\
\hline & Eastern hemlock (Tsuga canadensis (L.) Carrière) & $38 \pm 4$ & 30 & 46 \\
\hline \multirow[t]{3}{*}{ Bartlett Experimental Forest } & Red maple (Acer rubrum L.) & $35 \pm 8$ & 25 & 48 \\
\hline & Paper birch (Betula papyrifera Marsh.) & $33 \pm 5$ & 25 & 43 \\
\hline & American beech (Fagus grandifolia Ehrh.) & $31 \pm 5$ & 25 & 46 \\
\hline \multirow[t]{3}{*}{ Harvard Forest } & Red maple (Acer rubrum L.) & $28 \pm 5$ & 23 & 43 \\
\hline & Red oak (Quercus rubra L.) & $42 \pm 9$ & 25 & 69 \\
\hline & Eastern hemlock (Tsuga canadensis (L.) Carrière) & $40 \pm 8$ & 23 & 56 \\
\hline
\end{tabular}

each increment core. Cores were vacuum-infiltrated with $80 \%$ ethanol at $-52 \mathrm{KPa}$ for $15 \mathrm{~min}$ and then boiled. Samples were finely diced with a razor blade and macerated in existing ethanol solutions using a polytron (Brinkman Instruments, Westbury, MA, USA). Macerated samples were extracted twice with $5 \mathrm{ml}$ fresh $80 \%$ ethanol at $80^{\circ} \mathrm{C}$ for $15 \mathrm{~min}$ and centrifuged at $3000 \mathrm{rpm}$. Supernatants for each sample were combined, filtered through a $0.45 \mu \mathrm{m}$ syringe filter and used for soluble sugar analysis. The ethanol-insoluble pellets were used to determine starch content.

Ethanol-soluble fractions were analysed for sucrose, glucose, fructose, raffinose, and stachyose using a Waters (Milford, MA, USA) Alliance high-pressure liquid chromatography (HPLC) system with a Waters Sugar-pak column and solvent $\left(0.1 \mathrm{mmol}^{-1}\right.$ Ca EDTA) at $90^{\circ} \mathrm{C}$ (Wong et al., 2003). Sugars were detected with a Waters 2414 refractive index detector and Waters PCbased Empower software. The separated soluble sugars were identified and quantified with known standards and converted to mg sugar per g oven-dry wood.

The branched form of starch was determined after gelatinization with $0.1 \mathrm{M} \mathrm{KOH}$ in a boiling water bath for $30 \mathrm{~min}$ followed by neutralization with acetic acid by hydrolysis with amyloglucosidase for $30 \mathrm{~min}$ at $55^{\circ} \mathrm{C}$ (Wargo et al., 2002). Enzymatic digestions were terminated by placing the digests in a boiling water bath for $4 \mathrm{~min}$. Glucose formed by hydrolysis was determined with a glucose hexokinase kit (Pointe Scientific, Canton, MI, USA) at $340 \mathrm{~nm}$ with a microplate reader (ELx800
UV; Bio-Tek Instruments, Winooski, VT, USA). Starch concentrations were calculated from standard curves and are expressed here as mg starch per g oven-dry wood.

The standard deviation (across trees of the same species on a given sampling date) of the total (starch + sugars) stemwood NSC was $1 \sigma= \pm 25 \%$ of the measured value. With $n=10$ replicate trees per species at each sample date, the standard error on the species-level mean is thus $c . \pm 9 \%$.

\section{Determination of ${ }^{14} \mathrm{C}$-based ages}

We took advantage of the ${ }^{14} \mathrm{C}$ bomb spike to directly estimate the age of extracted NSC. This approach uses the ${ }^{14} \mathrm{C}$ label that was produced during the period of atmospheric thermonuclear weapons testing, which approximately doubled the ${ }^{14} \mathrm{C}$ content of $\mathrm{CO}_{2}$ in the northern hemisphere atmosphere by 1963 (Fig. 2a). Since then, the ${ }^{14} \mathrm{C}$ content of atmospheric $\mathrm{CO}_{2}$ has decreased owing to dilution through mixing with ocean and biosphere $\mathrm{C}$ reservoirs, and by the addition of ${ }^{14} \mathrm{C}$-free $\mathrm{CO}_{2}$ from fossil fuel burning (Levin et al., 2010). We estimated the ages of stemwood starch, sugars and ring cellulose by direct comparison with the northern hemisphere atmospheric record (Levin et al., 2008; I. Levin, pers. comm.) following Gaudinski et al. (2001). This is possible because the $\mathrm{C}$ in photosynthate reflects the ${ }^{14} \mathrm{C}$ content of the atmosphere in the year assimilation occurred and contributes to the NSC pool ${ }^{14} \mathrm{C}$ content. For pools with a mean residence time (MRT) of $<20 \mathrm{yr}$, the ${ }^{14} \mathrm{C}$ age of the pool is 


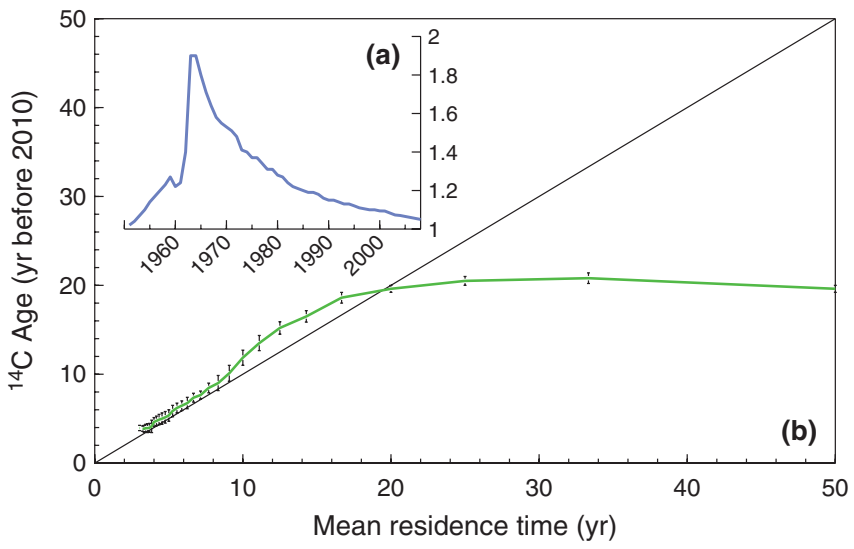

Fig. 2 (a) Relative amount of ${ }^{14} \mathrm{C}$ in newly assimilated $\mathrm{C}$, based on the atmosphere ${ }^{14} \mathrm{C}$ record of Levin \& Kromer (2004). (b) Comparison of ${ }^{14} \mathrm{C}$ age in 2010 ( $y$-axis) and mean residence time (MRT, $x$-axis) of simulated well-mixed pools. Simulations were conducted by incorporating various fractions (1/MRT per year) of new assimilates, labeled with the atmospheric ${ }^{14} \mathrm{C}$ trajectory shown in (a), each year. For pools with a relatively fast turnover (mean residence time, MRT, of $<20 \mathrm{yr}$ ), the ${ }^{14} \mathrm{C}$ age of the pool is approximately equal to the MRT of the pool, but for slower turnover pools (MRT $>20 \mathrm{yr}$ ), the relatively small amount of new material incorporated each year (e.g. a pool with a 33-yr MRT incorporates $3 \%$ new material each year) and the short duration of the peak ${ }^{14} \mathrm{C}$ years means that the spike is not fully incorporated in the pool (in other words, an appreciable amount of pre-bomb carbon is present to dilute the spike). The apparent ${ }^{14} \mathrm{C}$ age of the pool does not equate to MRT when the MRT > $20 \mathrm{yr}$.

approximately equal to the MRT of the pool (Fig. 2b). Assuming steady-state conditions, this approach can quantify the MRT of $\mathrm{C}$ in the NSC pool.

For our ${ }^{14} \mathrm{C}$-NSC analysis, only the outer $2 \mathrm{~cm}$ of each core was used. Samples were placed in clean glass vials and oven-dried for $2 \mathrm{~d}$ at $60^{\circ} \mathrm{C}$ before being shipped to UC Irvine for extraction and analysis. Soluble NSC (sugars, isolated by hot-water extraction) and insoluble NSC (starches, isolated by acid digestion following lipid removal by boiling in ethanol) were sequentially extracted from each core sample (C. Czimczik et al., unpublished). Other existing methods, such as that developed by Wong et al. (2003), cannot be applied to isolate NSC for ${ }^{14} \mathrm{C}$ analysis because they introduce too much extraneous $\mathrm{C}$, which alters the ${ }^{14} \mathrm{C}$ content of the sample. Our data indicate reasonably good agreement between NSC concentrations measured following Wong et al. (2003) and the yield of the extractions at UC Irvine $(r=0.74$, based on sugar in cores from $n=26$ red maple trees; see Notes S1, Fig. S2). Holocellulose was extracted from the wood in the last ring of each $2 \mathrm{~cm}$ core using the procedure described by Leavitt \& Danzer (1993).

Extracted starch, sugars, and ring cellulose were combusted to $\mathrm{CO}_{2}$, purified on a vacuum line, and converted to graphite $(\mathrm{Xu}$ et al., 2007). Graphite was analysed for its ${ }^{14} \mathrm{C}$ content at the W.M. Keck Carbon Cycle Accelerator Mass Spectrometry facility at UC Irvine (KCCAMS, Southon et al., 2004). Unknown samples were analysed alongside blanks (coal) and standards (OXI, OXII, IAEA C-6). All ${ }^{14} \mathrm{C}$ data are reported in Fraction modern $\left(\mathrm{F}^{14} \mathrm{C}\right.$, Eqn 1$)$, which is the ratio of ${ }^{14} \mathrm{C}$ to ${ }^{12} \mathrm{C}$ in a sample divided by that of a standard of fixed isotopic composition (0.95 times the ${ }^{14} \mathrm{C} /{ }^{12} \mathrm{C}$ of oxalic acid I standard). Measurements have been corrected for the effects of mass-dependent isotope fractionation by normalizing to a common $\delta^{13} \mathrm{C}$ value $(-25 \%)$ and assuming ${ }^{14} \mathrm{C}$ is fractionated twice as much as ${ }^{13} \mathrm{C}$ (Reimer et al., 2004).

$\mathrm{F}^{14} \mathrm{C}=\frac{\left[{ }^{14} \mathrm{C} /{ }^{12} \mathrm{C}\right] \text { sample },-25}{0.95\left[{ }^{14} \mathrm{C} /{ }^{12} \mathrm{C}\right] \mathrm{OXI},-19}$

Eqn 1

Known ${ }^{14} \mathrm{C}$ standards of rye flour, wheat flour, and IAEA C-6 were processed with samples to quantify the NSC extraction error, which was the same $\left(< \pm 0.0050 \mathrm{~F}^{14} \mathrm{C}\right)$ for both starch and sugars. The measurement precision from the KCCAMS was $< \pm 0.0020 \mathrm{~F}^{14} \mathrm{C}$. Given the rate of decline in atmospheric ${ }^{14} \mathrm{C}$ (c. $0.0045 \mathrm{~F}^{14} \mathrm{C} \mathrm{yr}^{-1}$ over the last decade, with much greater annual declines in previous decades) our total measurement error makes it possible to resolve NSC ages to $\pm 1-2 \mathrm{yr}$.

Previous ${ }^{14} \mathrm{C}$ samples at Harvard Forest and Howland Forest ( $n=45$ from 1996-2002) have shown that background air is consistent with the established record (S. Trumbore, unpublished). For further verification we collected flask samples of air and tissue samples from an annual plant, jewelweed (Impatiens capensis), at Bartlett Experimental Forest and Harvard Forest during the summer of 2011. Annual plants are good samplers of the background air because the ${ }^{14} \mathrm{C}$ content in their structural tissues reflects an average value, integrated over weeks-to-months, for the current growing season (e.g. Hsueh et al., 2007). These data indicate a mean atmospheric ${ }^{14} \mathrm{CO}_{2}$ value of $1.0432\left(\mathrm{~F}^{14} \mathrm{C}\right)$ during the growing season of 2011, in agreement with the established northern hemisphere record (Levin et al., 2008; I. Levin, pers. comm.) and the mean of atmospheric measurements from May to September 2011 at Point Barrow, AK (1.0432 \pm 0.0017 , $n=19 ; \mathrm{X} . \mathrm{Xu}$, unpublished).

\section{Tree ring counts and growth rates}

Cores for ring width measurements were mounted, dried and sanded. Rings were measured to the nearest $0.01 \mathrm{~mm}$ using a sliding stage unit (Velmex Inc., Bloomfield, NY, USA) with MeasureJ2X software (VoorTech Consulting, Holderness, NH, USA) according to methods of Stokes \& Smiley (1968). The computer program COFECHA was used to cross-date and identify areas of cores that may contain false or locally absent rings (Holmes, 1983). We converted ring width data to basal area increments (BAI, $\mathrm{cm}^{2} \mathrm{yr}^{-1}$ ), assuming a circular outline of stem cross-sections (Cook \& Kairiukstis, 1990). In addition to the total number of rings in the core, we counted the number of rings in the outer $2 \mathrm{~cm}$ of stemwood, corresponding to the tissue used for NSC and ${ }^{14} \mathrm{C}-\mathrm{NSC}$ analyses.

\section{Modeling of NSC seasonal dynamics}

We ran the FöBAAR (FOrest Biomass, Allocation, Assimilation and Respiration; Keenan et al., 2012) model at Howland Forest to assess different allocation schemes. Following a model-data 
fusion approach (Fox et al., 2009; Keenan et al., 2011), eddy covariance $\mathrm{CO}_{2}$ flux measurements, biometric inventories and periodic measurements of soil respiration, soil $\mathrm{C}$, leaf area index and litterfall were used to constrain the model parameterization and initial conditions. Richardson et al. (2010) describe the data, including field methods and uncertainty estimates, in greater detail.

We compared three versions of FöBAAR. The first (Keenan et al., 2012; Fig. 3a) features a static C allocation scheme. At each time-step, a fixed proportion of current photosynthate is immediately lost as autotrophic respiration, and the remainder is allocated to one of three C pools: foliage, roots and wood. There is no storage pool.

In the second version of the model (Fig. 3b), photosynthate at each time step is first passed to a dynamic storage pool, from which $\mathrm{C}$ may then be allocated to foliage, roots and wood. The storage pool builds up when current photosynthate is greater than $\mathrm{C}$ allocation and is drawn down when the reverse occurs. This version partitions autotrophic respiration to growth and maintenance components (Thornley \& Cannell, 2000; Le Roux et al., 2001). Growth respiration is proportional to the allocation to wood, roots and foliage, whereas maintenance respiration is temperature-sensitive and proportional to biomass. As a sensitivity analysis, we conducted three different runs: first, the initial size of the storage pool was optimized but not directly constrained; second, the MRT of the storage pool was constrained with ${ }^{14} \mathrm{C}$ NSC age estimates; third, the initial size of the storage pool was constrained to $1000 \mathrm{~g} \mathrm{~m}^{-2}$.

In the third version of the model (Fig. 3c), there are two storage pools, representing 'fast' and 'slow' cycling reserves. We note these are functional definitions and it is not our intent for these two model pools to represent stemwood sugars and starch, respectively. All current photosynthate is first passed to the fast pool and allocation to growth occurs from the fast pool, and in proportion to its size, subject to phenological constraints. Transfers between the fast and slow pools occur in proportion to the gradient between the two. We again conducted a variety of sensitivity experiments, using a two-factor (total pool size, and fast pool MRT) design. For the first factor, we forced the initial size of the total (fast + slow) pool to $500 \mathrm{~g} \mathrm{~m}^{-2}, 1000 \mathrm{~g} \mathrm{~m}^{-2}$ and $2000 \mathrm{~g} \mathrm{~m}^{-2}$; for the second factor, we forced the MRT of the fast pool to vary between $0.25 \mathrm{yr}$ and $1.5 \mathrm{yr}$. In all cases, we then constrained the size-weighted MRT of the total (fast + slow) NSC pool with the ${ }^{14} \mathrm{C}-\mathrm{NSC}$ age estimates, and solved directly for the MRT of the slow pool.

In some of these model runs, we elected to constrain the total NSC pool size to be $\approx 1000 \mathrm{~g} \mathrm{C} \mathrm{m}^{-2}$. We argue that this value is consistent with the concentration measurements, assuming that our stemwood concentrations can be extrapolated to all aboveground woody biomass, NSCs are c. $40 \%$ C, dry wood is $50 \%$ $\mathrm{C}$, the woody root:shoot ratio is 1:5 and NSCs in aboveground wood comprise $25 \%$ of the total NSC pool (Gholz \& Cropper, 1991; cf. Würth et al., 2005; Gough et al., 2009). Our model runs with total $\mathrm{NSC} \approx 500$ and $2000 \mathrm{~g} \mathrm{C} \mathrm{m}^{-2}$ are used to show that a smaller, or larger, total pool size is also possible and still consistent with the ${ }^{14} \mathrm{C}-\mathrm{NSC}$ age estimates.

\section{Results}

\section{Partitioning of total NSCs, and differences among species}

Across all species and collection dates, concentrations of total NSC averaged $22.4 \pm 4.4 \mathrm{mg} \mathrm{NSC} \mathrm{g}^{-1}$ oven-dry wood (total = starch + sugars, mean $\pm 1 \mathrm{SD}$ ). The highest concentrations were measured for starch (mean $10.4 \mathrm{mg} \mathrm{g}^{-1}$ ) and sucrose $\left(5.7 \mathrm{mg} \mathrm{g}^{-1}\right)$, with lower concentrations measured for fructose $\left(3.0 \mathrm{mg} \mathrm{g}^{-1}\right)$ and glucose $\left(2.6 \mathrm{mg} \mathrm{g}^{-1}\right)$. Raffinose and stachyose were generally found only at very low concentrations: the mean concentration of both was $0.4 \mathrm{mg} \mathrm{g}^{-1}$, and higher concentrations were measured only during the winter months.

We observed large differences among species both in total NSC, and differences in how stemwood NSCs were partitioned (Fig. S3). Generally, the deciduous species (e.g. red maple, red oak, American beech, $>24 \mathrm{mg} \mathrm{NSC} \mathrm{g}{ }^{-1}$ ) had higher total NSC concentrations than the evergreen species (red spruce and eastern hemlock, $<20 \mathrm{mg} \mathrm{NSC}^{-1}$ ). The highest total NSC concentrations ( $42 \mathrm{mg} \mathrm{NSC} \mathrm{g}^{-1}$ ) were observed in red oak, a ring porous species that relies on stored reserves to produce new xylem each
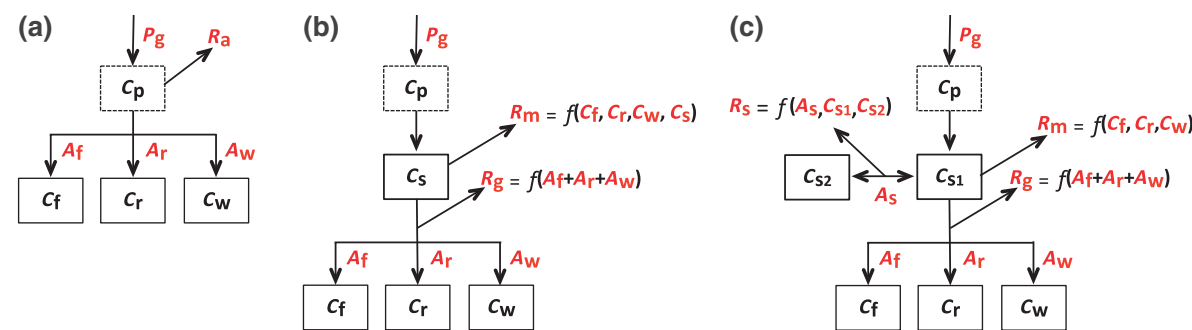

Fig. 3 Candidate representations of storage, allocation and autotrophic respiration processes and pathways in the FöBAAR model. (a) No storage pool, lumped autotrophic respiration proportional to gross photosynthesis; (b) one storage pool, separate growth and maintenance respiration components; (c) two storage pools ('fast' and 'slow' cycling reserves), with three separate respiration components. Pools, shown in boxes and labeled in black: $\mathrm{C}_{\mathrm{p} \text {, }}$ photosynthetic assimilates; $C_{f}, C$ in foliage; $C_{r}, C$ in fine roots; $C_{w}, C$ in wood; $C_{s}$, storage $C\left(C_{s 1}\right.$, fast pool; $C_{s 2}$, slow pool). Fluxes, denoted by arrows and labeled in red: $P_{g}$ gross photosynthesis; $A_{f}$ allocation to foliage; $A_{r}$, allocation to fine roots; $A_{w}$, allocation to wood; $A_{s}$ allocation to/from long-term storage; $R_{a}$ l lumped autotrophic respiration; $R_{m}$, maintenance respiration; $R_{g}$, growth respiration; $R_{s}$, metabolic cost of storage and interconversion between fast and slow pools. The dotted line around the $C_{p}$ pool indicates that this is a temporary pool; in a given time-step, photosynthetic assimilates are either immediately allocated to growth (model a) or passed to a dynamic storage pool. 
spring in advance of leaf out. At Bartlett, low total NSC concentrations (13 $\mathrm{mg} \mathrm{NSC} \mathrm{g}^{-1}$ ) in paper birch were associated with high rates of mortality ( 4 of 20 trees) over the course of this fieldwork (for further analysis, see Notes S2, Fig. S4). Starch accounted for a somewhat smaller proportion of total NSCs (35\%) in American beech than in most other species (e.g. red maple, 46-51\% across all three sites). For red oak and American beech, fructose accounted for a much higher proportion (20\%) of total NSCs compared with other species, particularly red maple (5-10\% across all three sites). In the evergreen species eastern hemlock and red spruce, sucrose accounted for a lower proportion of total NSCs $(15-17 \%)$ than in any of the deciduous species $(22-32 \%)$.

\section{Seasonal dynamics of starch and sugars}

Across sampling periods, our data indicated dynamic changes in total NSCs and the partitioning between starch and sugars (Fig. 4). The variability in total NSCs was, in most cases, only weakly seasonal (Table S1). By comparison, seasonal patterns explained most of the variation in stemwood sugar concentrations (all $R^{2}>0.60, P \leq 0.05$; Table $S 1$ ). In all species, sugar concentrations were between two and four times higher during the dormant season (November and March) than during the growing season (June and August). A decline in sugar concentrations (and typically total NSC) was consistently observed for all species between March and June. This may indicate that strong sinks, associated with the springtime growth of new roots, wood and foliage, are drawing down the stemwood NSC reserves as C demand exceeds what is being concurrently produced by photosynthesis.

Seasonal patterns also explained a significant proportion of the variation in stemwood starch concentrations (Table S1; note the trees at Harvard Forest as an exception). Starch concentrations were between two and five times higher during the growing season than during the dormant season (Fig. 4), and thus the seasonal dynamics of starch generally mirrored those of sugar. Accompanying the decline in sugar concentrations from March to June was a somewhat smaller increase in starch concentrations over the same period.

For red maple, seasonal changes in starch and sugars were nearly identical at all three sites (Fig. 4, left column). For eastern hemlock (Fig. 4, right column top and bottom), similar peaks in sugar concentrations in March 2008, and starch concentrations in June 2009, were observed at both sites. For a given species, the seasonal patterns are thus highly robust across sites, suggesting regionally consistent responses to broad-scale weather and climate drivers (Fig. S1) or internal phenology, and a lesser influence of site-specific factors such as site history or disturbance.

\section{${ }^{14} \mathrm{C}$-based estimates of NSC ages}

Radiocarbon estimates of NSC ages showed that, in many cases, the starch and sugars extracted from stemwood cores were both surprisingly old. Across species and sites, the age of starch ranged from 1 to $31 \mathrm{yr}$ and sugars from 1 to $24 \mathrm{yr}$ (site
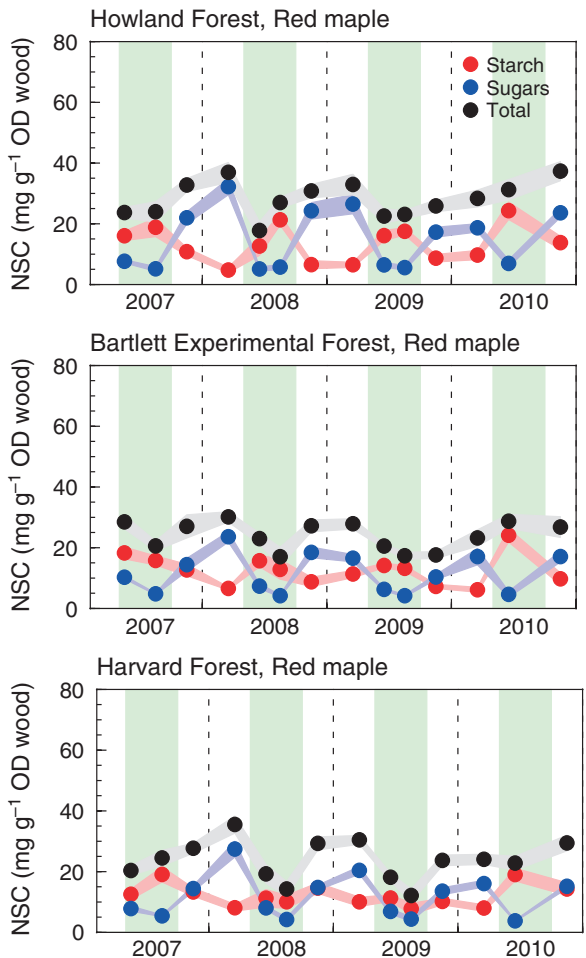

Howland Forest, Red spruce
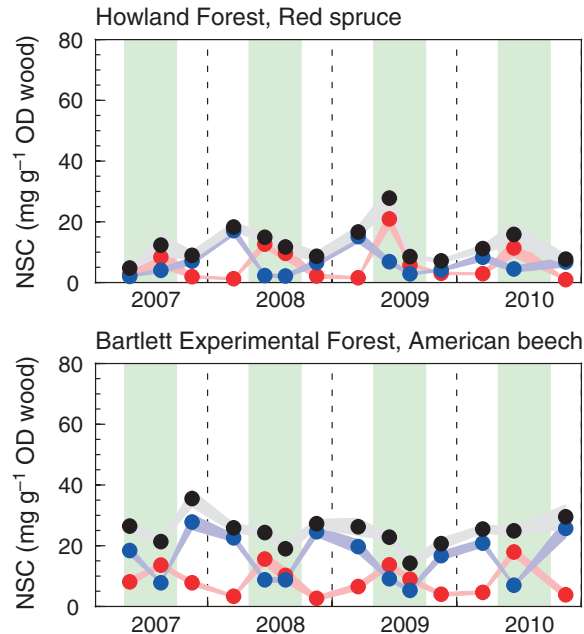

Harvard Forest, Red oak

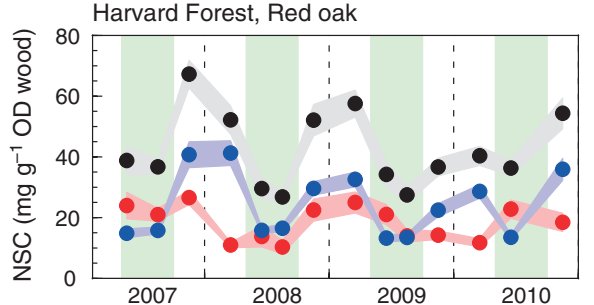

Howland Forest, Eastern hemlock
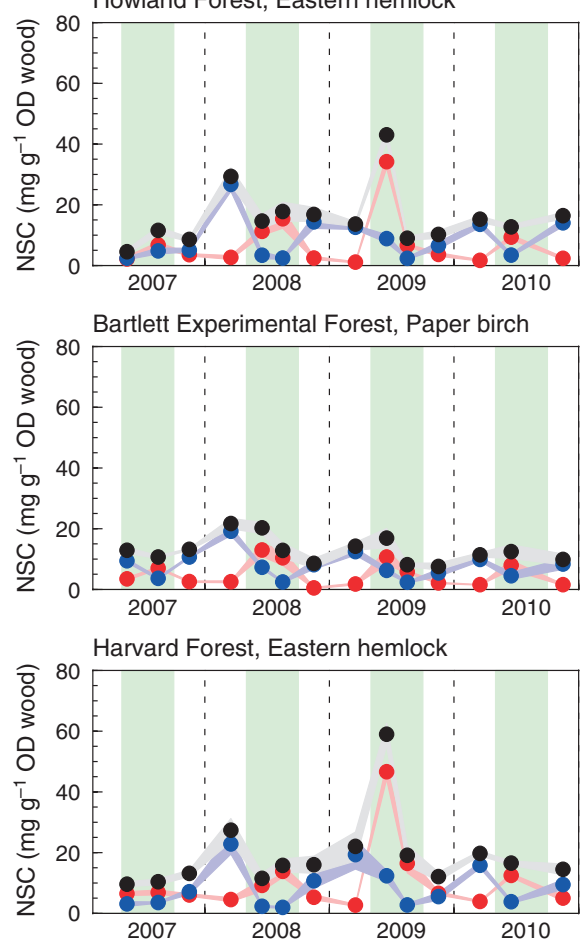

Fig. 4 Seasonal dynamics of stemwood concentrations of nonstructural carbohydrates (NSC, starch and sugars, representing the sum of sucrose, glucose, fructose, raffinose, and stachyose) in forest trees. Sampling conducted across a range of deciduous and evergreen species at three study sites. Symbols indicate means across $n=10$ trees of each species sampled on each date. Shading indicates $\pm 1 \mathrm{SE}$ of the mean. Green shading denotes peak growing season, from May to September. Dashed vertical lines indicate January 1. 
means and standard deviations are shown in Table 3). The mean age of NSCs (i.e. starch + sugars, concentration-weighted ages) in the red maple cores was $12.4 \pm 8.8 \mathrm{yr}$ at Howland Forest (mean tree age $133 \pm 39 \mathrm{yr}$ ), $14.2 \pm 5.2 \mathrm{yr}$ at Bartlett Experimental Forest (mean tree age $115 \pm 19 \mathrm{yr}$ ), and $7.2 \pm$ $7.7 \mathrm{yr}$ at Harvard Forest (mean tree age $80 \pm 12 \mathrm{yr}$ ), with a mean across all sites of $11.5 \pm 7.4 \mathrm{yr}$. The ages of the starch and sugars were linearly related $(r=0.97, P<0.01, x=$ starch, $y=$ sugar, slope $=0.61 \pm 0.04$, intercept $=4.3 \pm 0.59)$, but the slope of the regression was significantly different from 1 $(P<0.01)$, implying that the starch was older than the corresponding sugars.

The mean age of sugars in the eastern hemlock cores was younger than in the red maple cores $(6.8 \pm 4.9$ vs $11.1 \pm 6.3 \mathrm{yr}$, respectively, $P<0.01$ by $t$-test). Thus, the deciduous red maple had higher stemwood NSC concentrations and older NSCs, compared with the evergreen eastern hemlock. This result may reflect the different growth strategies of the species, in which the red maple is likely more conservative with its reserves because it experiences a shorter growing season and must replenish its canopy annually, whereas eastern hemlock can potentially photosynthesize year-round if environmental conditions are favorable.

We saw no evidence of a relationship between the concentration and age of stemwood sugars in red maple or eastern hemlock, but the data did suggest a negative relationship between the concentration and age of stemwood starch in red maple $(r=-0.44, P=0.03)$.

Among red maple trees, observable characteristics such as canopy position or crown vigor could not explain the measured differences in NSC ages. However, the age of sugar and starch in each $2 \mathrm{~cm}$ stemwood core was positively related to the ${ }^{14} \mathrm{C}$ content in the extracted cellulose from the oldest ring of that core $(r=0.93$ and 0.88 for sugar and starch, respectively, $P<0.01$ ), the number of measured rings in the outer $2 \mathrm{~cm}$ of each tree $(r=0.73$ for both sugar and starch, both $P<0.01)$ and the tree age $(r=0.66$ and 0.61 for sugar and starch respectively, $P<0.01)$. Based on these observations, we expect that a deeper core $(>2 \mathrm{~cm})$ would integrate over older NSC than a shallower core and thus our measurements most likely underestimate the age of the total NSC reserves.

\section{Modeling NSC dynamics and age}

The success of our inverse modeling with FöBAAR was dependent on the representation of $\mathrm{C}$ allocation and storage. We conducted modeling runs for Howland Forest and, motivated by the results shown in Fig. 1, we evaluated the model against previously-collected woody biomass increment data (Richardson et al., 2010) and the NSC measurements reported above (Table 4). Note that all versions of the model were able to reproduce the variability in measured $\mathrm{NEE}$, to a more or less similar degree, at hourly $\left(\mathrm{RMSE} \approx 0.14 \pm 0.01 \mathrm{~g} \mathrm{C} \mathrm{m}^{-2} \mathrm{~h}^{-1}\right.$ ), daily (RMSE $\approx$ $1.05 \pm 0.05 \mathrm{gC} \mathrm{m}^{-2} \mathrm{~d}^{-1}$ ) and annual (RMSE $\approx 80 \pm$ $10 \mathrm{~g} \mathrm{C} \mathrm{m}^{-2} \mathrm{yr}^{-1}$ ) time-scales.

The first version of the model, with no storage pool and immediate allocation of photosynthetic products to growth and respiration (Fig. 3a), was unable to reproduce the observed interannual variability in woody biomass increment (Table 4 , $r=0.56, P=0.12$, with a slope on the relationship between predicted and measured that was $<0.5$ ) and is inconsistent with observations of storage reserves that are both dynamic and, on average, old.

The second version of the model, with a one-pool representation of NSC reserves, also performed poorly for interannual variability in biomass increment, regardless of what constraints we applied to NSC pool size or MRT (Table 4, all one-pool runs $r<0.60, P>0.10)$. With the one-pool model, we found that that when NSC pool was itself not directly constrained, its mean size ( $230 \mathrm{~g} \mathrm{C} \mathrm{m}^{-2}$ ) was quite small, and its MRT was too fast $(0.3 \mathrm{yr})$. When we constrained the MRT of the pool to match with ${ }^{14} \mathrm{C}$ NSC observations, the size of the pool was too large (9400 $\mathrm{g} \mathrm{C} \mathrm{m}^{-2} \mathrm{yr}^{-1}$ ) - almost as large as the woody biomass pool itself. When we constrained the size of the pool to be $1000 \mathrm{~g} \mathrm{C} \mathrm{m}^{-2} \mathrm{yr}^{-1}$, its MRT was still too fast (1.20 yr).

The third version of the model, with a two-pool representation, performed best. While the pool sizes and turnover times are

Table 3 The ${ }^{14} \mathrm{C}$ content, in Fraction modern notation $\left(\mathrm{F}^{14} \mathrm{C}\right)$, and ${ }^{14} \mathrm{C}$-based age (yr) for stemwood sugar and starch in the $2 \mathrm{~cm}$ core, and cellulose in the oldest ring of the same $2 \mathrm{~cm}$ core

\begin{tabular}{|c|c|c|c|c|c|c|c|}
\hline \multirow[b]{2}{*}{ Site } & \multirow[b]{2}{*}{ Species } & \multicolumn{2}{|l|}{ Sugar } & \multicolumn{2}{|l|}{ Starch } & \multicolumn{2}{|l|}{ Cellulose } \\
\hline & & $\mathrm{F}^{14} \mathrm{C}$ & Age & $\mathrm{F}^{14} \mathrm{C}$ & Age & $\mathrm{F}^{14} \mathrm{C}$ & Age \\
\hline Howland Forest & $\begin{array}{l}\text { Red maple } \\
\text { Eastern hemlock }\end{array}$ & $\begin{array}{l}1.1087 \pm 0.0466 \\
1.0900 \pm 0.0326\end{array}$ & $\begin{array}{r}12.4 \pm 7.1 \\
9.4 \pm 5.6\end{array}$ & $\begin{array}{c}1.1236 \pm 0.0856 \\
\text { na }\end{array}$ & $\begin{array}{l}12.9 \pm 10.8 \\
\mathrm{na}\end{array}$ & $\begin{array}{c}1.2600 \pm 0.2283 \\
\mathrm{na}\end{array}$ & $\begin{array}{l}24.6 \pm 10.9 \\
\text { na }\end{array}$ \\
\hline Bartlett Experimental Forest & Red maple & $1.1119 \pm 0.0326$ & $13.0 \pm 4.9$ & $1.1347 \pm 0.0663$ & $15.5 \pm 7.8$ & $1.3152 \pm 0.1499$ & $30.8 \pm 7.2$ \\
\hline Harvard Forest & $\begin{array}{l}\text { Red maple } \\
\text { Eastern hemlock }\end{array}$ & $\begin{array}{l}1.0818 \pm 0.0344 \\
1.0641 \pm 0.0112\end{array}$ & $\begin{array}{l}7.5 \pm 5.8 \\
4.4 \pm 2.7\end{array}$ & $\begin{array}{c}1.0760 \pm 0.0564 \\
\mathrm{na}\end{array}$ & $\begin{array}{l}6.1 \pm 8.8 \\
\text { na }\end{array}$ & $\begin{array}{c}1.1951 \pm 0.1715 \\
\text { na }\end{array}$ & $\begin{array}{l}19.2 \pm 12.3 \\
\text { na }\end{array}$ \\
\hline All & $\begin{array}{l}\text { Red maple } \\
\text { Eastern hemlock }\end{array}$ & $\begin{array}{l}1.1015 \pm 0.0393 \\
1.0763 \pm 0.0266\end{array}$ & $\begin{array}{r}11.1 \pm 6.3 \\
6.8 \pm 4.9\end{array}$ & $\begin{array}{c}1.1119 \pm 0.0728 \\
\mathrm{na}\end{array}$ & $\begin{array}{l}11.6 \pm 9.8 \\
\mathrm{na}\end{array}$ & $\begin{array}{c}1.2565 \pm 0.1817 \\
\mathrm{na}\end{array}$ & $\begin{array}{l}24.9 \pm 11.1 \\
\text { na }\end{array}$ \\
\hline
\end{tabular}

Only sugar was measured for Eastern hemlock cores. All values are reported as mean values \pm 1 SD, based on $n=9$ individual trees for each site and $n=27$ (red maple) and $n=18$ (eastern hemlock) for all sites combined. na, not applicable. 
Table 4 Sensitivity of model goodness-of-fit to different model structures (no, one, and two storage pool representations) and constraints set for these pools (no constraints, size constrained or size-weighted MRT (mean residence time) constrained)

\begin{tabular}{|c|c|c|c|c|c|c|c|c|c|c|}
\hline \multirow[b]{3}{*}{ Model structure } & \multirow{2}{*}{\multicolumn{2}{|c|}{$\begin{array}{l}\text { Fast storage } \\
\text { pool }\end{array}$}} & \multirow{2}{*}{\multicolumn{2}{|c|}{$\begin{array}{l}\text { Slow storage } \\
\text { pool }\end{array}$}} & \multicolumn{6}{|c|}{ Goodness of fit } \\
\hline & & & & & \multicolumn{3}{|c|}{ NEE RMSE } & \multicolumn{3}{|c|}{ Annual $C_{w}$ Increment } \\
\hline & $\begin{array}{l}\text { Mean size } \\
\left(\mathrm{gC} \mathrm{m}^{-2}\right)\end{array}$ & $\begin{array}{l}\text { MRT } \\
(\mathrm{yr})\end{array}$ & $\begin{array}{l}\text { Mean size } \\
\left(\mathrm{gC}^{-2}\right)\end{array}$ & $\begin{array}{l}\text { MRT } \\
(\mathrm{yr})\end{array}$ & $\begin{array}{l}\text { Hourly } \\
\left(\mathrm{gC} \mathrm{m}^{-2}\right. \\
\left.\mathrm{h}^{-1}\right)\end{array}$ & $\begin{array}{l}\text { Daily } \\
\left(\mathrm{gCm}^{-2}\right. \\
\left.\mathrm{d}^{-1}\right)\end{array}$ & $\begin{array}{l}\text { Annual } \\
\left(\mathrm{gC} \mathrm{m}^{-2}\right. \\
\left.\mathrm{yr}^{-1}\right)\end{array}$ & $\begin{array}{l}\text { RMSE } \\
\left(\mathrm{gC} \mathrm{m}^{-2}\right. \\
\left.\mathrm{yr}^{-1}\right)\end{array}$ & $\begin{array}{l}\text { Pearson's } \\
r\end{array}$ & $\begin{array}{l}\text { Slope } \\
\left(\mathrm{g} \mathrm{g}^{-1}\right)\end{array}$ \\
\hline No storage pool & - & - & - & - & 0.174 & 0.99 & 79.7 & 11.3 & 0.56 & 0.47 \\
\hline One pool (no constraints) & 230 & 0.3 & - & - & 0.134 & 1.04 & 95.0 & 9.4 & 0.53 & 0.55 \\
\hline One pool (MRT constrained) & 9400 & 10.7 & - & - & 0.133 & 0.91 & 85.9 & 10.0 & 0.39 & 0.14 \\
\hline One pool (size constrained) & 1000 & 1.2 & - & - & 0.136 & 0.99 & 85.6 & 8.9 & 0.57 & 0.10 \\
\hline \multirow{4}{*}{$\begin{array}{l}\text { Two pools } \\
\text { (MRT constrained, } \\
\text { total size } \approx 1000 \mathrm{~g})\end{array}$} & 220 & 0.25 & 860 & 14.1 & 0.135 & 1.09 & 68.8 & 10.2 & 0.60 & 1.18 \\
\hline & 330 & 0.50 & 730 & 16.4 & 0.146 & 1.08 & 87.6 & 8.7 & 0.70 & 1.09 \\
\hline & 560 & 0.75 & 470 & 24.4 & 0.141 & 1.15 & 84.7 & 8.9 & 0.67 & 1.04 \\
\hline & 740 & 1.00 & 310 & 36.8 & 0.143 & 1.13 & 86.2 & 9.1 & 0.68 & 1.13 \\
\hline \multirow{3}{*}{$\begin{array}{l}\text { Two pools } \\
(\text { MRT constrained, } \\
\text { total size } \approx 500 \mathrm{~g})\end{array}$} & 200 & 0.25 & 360 & 17.5 & 0.137 & 1.07 & 72.8 & 11.5 & 0.56 & 1.44 \\
\hline & 240 & 0.35 & 300 & 20.5 & 0.138 & 1.00 & 84.6 & 10.8 & 0.57 & 1.26 \\
\hline & 380 & 0.50 & 180 & 34.7 & 0.137 & 1.09 & 88.0 & 11.7 & 0.62 & 1.62 \\
\hline \multirow{4}{*}{$\begin{array}{l}\text { Two pools } \\
\text { (MRT constrained, } \\
\text { total size } \approx 2000 \mathrm{~g} \text { ) }\end{array}$} & 460 & 0.50 & 1730 & 13.9 & 0.136 & 1.13 & 57.8 & 8.9 & 0.69 & 1.13 \\
\hline & 600 & 0.75 & 1540 & 15.2 & 0.143 & 1.06 & 70.7 & 10.0 & 0.71 & 1.07 \\
\hline & 860 & 1.00 & 1230 & 18.3 & 0.138 & 1.17 & 69.9 & 8.5 & 0.70 & 1.00 \\
\hline & 1050 & 1.50 & 1120 & 20.2 & 0.148 & 1.06 & 84.3 & 8.3 & 0.73 & 1.12 \\
\hline
\end{tabular}

Goodness of fit is reported for net ecosystem exchange (NEE) of $\mathrm{CO}_{2}$ in terms of root mean squared error (RMSE) at hourly, daily, and annual time scales. For annual woody biomass $\left(C_{w}\right)$ increment, we report the RMSE in addition to the correlation coefficient (Pearson's $r$ ) between model predictions and observations, and the slope of the model $(y)$ vs observations $(x)$.

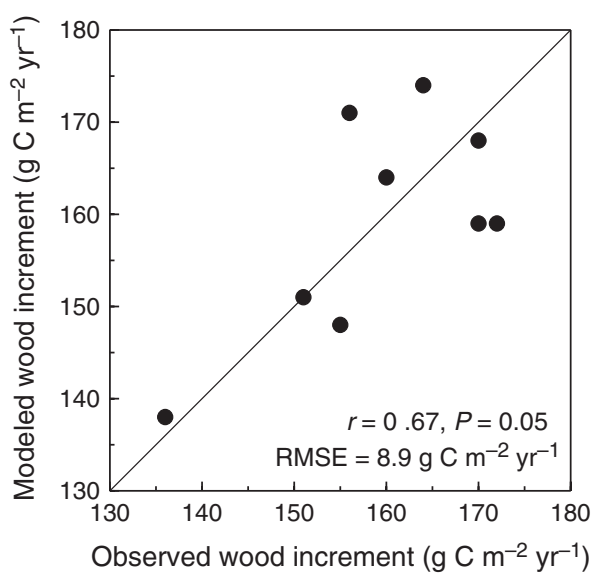

Fig. 5 Observed and modeled annual woody biomass increment (g C $\mathrm{m}^{-2} \mathrm{yr}^{-1}$ ) for Howland forest during the period 1996-2004, using the FöBAAR model with a two-pool representation of NSC reserves, as described in text and illustrated in Fig. 3(c) (fast pool: $560 \mathrm{~g} \mathrm{C} \mathrm{m}^{-2}$, $M R T=0.75 \mathrm{yr}$, slow pool: $470 \mathrm{~g} \mathrm{C} \mathrm{m}^{-2}, M R T=24.4 \mathrm{yr}$ ). The $1: 1$ line is illustrated (the linear regression of modeled wood increment on observed wood increment has an intercept of $-6 \mathrm{~g} \mathrm{C} \mathrm{m}^{-2} \mathrm{yr}^{-1}$ and a slope of $1.04 \mathrm{~g} \mathrm{~g}^{-1}$, and is virtually indistinguishable from the 1:1 line).

not uniquely determined, we note that a variety of different combinations offered a reasonable fit to the data. In all cases, however, model predictions of interannual variability in woody biomass increment were good (e.g. Fig. 5; Table 4). We highlight one particular run here as an example: with fast $\left(560 \mathrm{~g} \mathrm{C} \mathrm{m}^{-2}\right.$ and $\mathrm{MRT}=0.75 \mathrm{yr})$ and slow $\left(470 \mathrm{~g} \mathrm{C} \mathrm{m}^{-2}\right.$ and $\left.\mathrm{MRT}=24.4 \mathrm{yr}\right)$ cycling storage components, the size-weighted MRT of the total NSC pool was consistent with the ${ }^{14} \mathrm{C}-\mathrm{NSC}$ data $(\approx 11 \mathrm{yr})$. The size of the total NSC pool (Fig. 6) typically varied by c. $150 \mathrm{~g} \mathrm{C} \mathrm{m}^{-2}$ during the year, from a low in late spring when new growth is occurring to a peak at the end of the growing season, according to the balance between photosynthetic supply and metabolic demand. These seasonal dynamics were consistent with expectations, but inconsistent with our own concentration data (e.g. Fig. 5), which showed the highest total NSC concentrations in March $\left(27 \pm 13 \mathrm{~g} \mathrm{mg}^{-1}\right.$, mean $\pm 1 \mathrm{SD}$, across all trees and years) and the lowest in August $\left(17 \pm 9 \mathrm{~g} \mathrm{mg}^{-1}\right)$.

There was a gradual long-term increase in total NSC, roughly in proportion to the increase in woody biomass. After removing this trend, modeled interannual variability of the size of the total NSC pool was small (early-summer minima varying by $\approx 50 \mathrm{~g} \mathrm{C} \mathrm{m}^{-2} \mathrm{yr}^{-1}$, and late-summer maxima varying by $\approx 40 \mathrm{~g} \mathrm{C} \mathrm{m}^{-2} \mathrm{yr}^{-1} ; c .10 \%$ of the size of the fast pool, but just $5 \%$ of total NSC) compared with our measurements, which indicated interannual variability on the order of $\pm 10-20 \%$ for total NSC in each of the sampling periods (March, June, August, November).

Sensitivity analysis (Table 4) showed that: (1) a faster (e.g. $0.75 \rightarrow 0.25 \mathrm{yr})$ and hence smaller $(560 \rightarrow 220 \mathrm{~g})$ fast pool would need to be compensated for by a larger $(470 \rightarrow 860 \mathrm{~g})$ and faster 


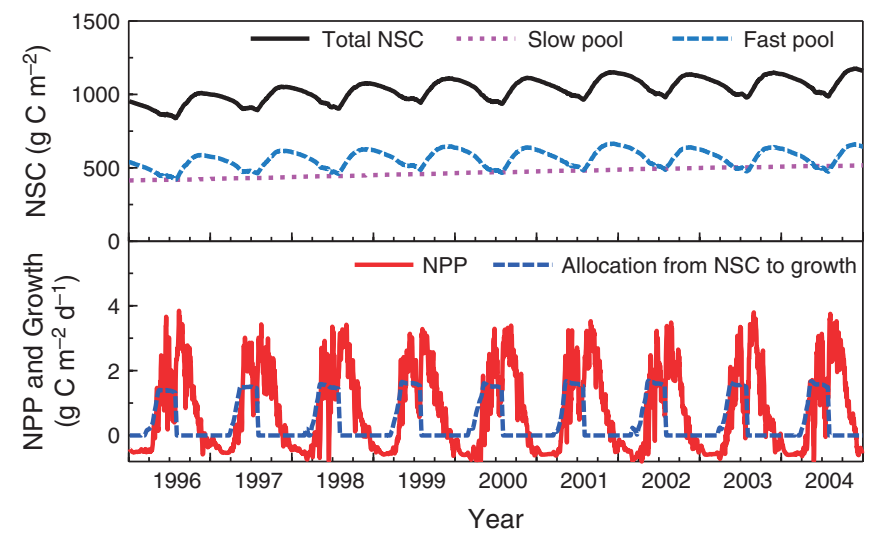

Fig. 6 Nonstructural carbohydrate (NSC) reserve pool dynamics (upper panel), daily net primary production (NPP) and allocation from NSC to growth (lower panel; note that these have been smoothed with a 7-d moving window), modeled with FöBAAR at Howland Forest. A two-pool (slow cycling reserves, short dash magenta line; fast cycling reserves, long dash blue line; aggregate NSC pool, solid black line) representation of NSC reserves was implemented. The size of the modeled NSC pool varies by $c$. $150 \mathrm{~g} \mathrm{C} \mathrm{m}^{-2}$ over the course of the year, reaching a minimum during spring, and a maximum at the end of the growing season. NSC reserves increase in late-summer, when NPP exceeds growth demands. NSC reserves decrease during the winter months (as stored NSCs are used to support maintenance respiration) and during the spring months (when both stored NSCs and current NPP are used to support new growth). The modeled increase in the total size of the NSC pool is roughly in proportion to the change in woody biomass over the same period.

$(24.4 \rightarrow 14.1 \mathrm{yr})$ slow pool in order to reproduce the measured MRT of the total pool, assuming the total pool size $\left(1000 \mathrm{~g} \mathrm{~m}^{-2}\right)$ is unchanged; and (2) if a different total NSC pool size is assumed (either $1000 \rightarrow 500 \mathrm{~g} \mathrm{C} \mathrm{m}^{-2}$ or $1000 \rightarrow 2000 \mathrm{~g} \mathrm{C} \mathrm{m}^{-2}$ ), comparable results could be obtained for a range of fast and slow pool MRT combinations.

\section{Discussion}

\section{Seasonal dynamics of measured stemwood NSC concentrations}

The seasonal dynamics indicated by our stemwood NSC measurements are somewhat unexpected. For example, we observed that sugar concentrations generally decreased, while starch concentrations increased, between March and June sampling dates. This could reflect conversion of sugars (which are readily transported and metabolically active) to starch (which is immobile and metabolically inert). Allocation to what is commonly viewed as long-term storage would seem surprising at a time of the year when metabolic demands peak. However, low sugar concentrations in the stemwood would keep sink demand high, fostering NSC transport out of the foliage and minimizing down-regulation of leaf photosynthetic rates.

Perhaps more curiously, for eight of the nine species-site combinations, total stemwood NSC concentrations were lower in August than June, and for seven of nine species-site combinations, total stemwood NSC concentrations were higher in March than November. Both of these trends appear to contradict the standard conceptual model (and our one- and two-pool model runs; Fig. 6), whereby (1) NSCs are replenished over the course of the summer growing season (e.g. increasing from June to August), when photosynthesis exceeds metabolic demands for $\mathrm{C}$ and (2) drawn down over the course of the dormant season (e.g. decreasing from November to March) when there is no photosynthesis but reserves are used to provide the energy required for maintenance respiration. However, broadly similar trends have been observed in some previous studies (e.g. Körner, 2003). We believe that our sampling of stemwood NSCs is providing an incomplete picture of the whole-tree NSC budget; substantial NSC reserves are also found in coarse roots, branches and foliage (when present) (e.g. Würth et al., 2005). The increase in total stemwood NSCs we observed from November to March may reflect remobilization of sugars from storage compartments in coarse roots, in advance of the $\mathrm{C}$ demands associated with springtime growth. Thus, stemwood concentrations can only serve as a rough indicator of the NSC status of the entire tree (Gaudillere etal., 1992). A more detailed accounting would be needed to understand how $\mathrm{C}$ demand and supply, together with sugarstarch interconversions, mixing of new and old carbohydrate reserves (e.g. Keel et al., 2007) and mobilization of reserves from storage in roots, stem and branches, contribute to dynamic changes in a tree's overall NSC budget.

\section{Age of the stemwood NSCs}

On average, the stemwood NSCs in these mature trees were about a decade old. Our sampling was restricted to the outer $2 \mathrm{~cm}$ of stemwood, and thus our measurements may underestimate the total stemwood NSC age, as we observed a relationship between the number of rings in the outer $2 \mathrm{~cm}$ and the age of the NSCs. However, we believe that our measurements are mostly representative because NSC concentrations rapidly decrease towards the center of the tree (Hoch et al., 2003).

We hypothesized that starch would be substantially older than sugars because starch is considered the longer-term storage form of NSC and is immobile (Chapin et al., 1990). However, starch and sugars were quite similar in age, which we interpret to mean that regular interconversion between starch and sugars must occur in the outer $2 \mathrm{~cm}$ of stemwood. This observation also argues against associating the fast pool (in the model) with sugars, and the slow pool with starch (cf. Chantuma et al., 2009). Thus, our distinction between the NSC pools in the model is made on functional grounds (fast vs slow cycling), rather than on the basis of chemical composition.

Our results corroborate estimates of NSC ages based on ${ }^{14} \mathrm{C}$ measurements of root respiration and new root biomass in forested ecosystems (Cisneros-Dozal et al., 2006; Czimczik etal., 2006; Schuur \& Trumbore, 2006; Carbone et al., 2007, 2011; Vargas etal., 2009). These studies showed that stored NSCs could range in age from 1 to $10 \mathrm{yr}$ old and together indicate that older NSCs are indeed accessible to the tree for metabolism and growth. Our stemwood NSCs are much older than the age of NSC determined by Gaudinski et al. (2009), who found stored NSC that formed new root tissue and leaf buds to be, on average, 
c. $0.7 \mathrm{yr}$ old, but our modeling analysis suggests that preferential allocation from a young (MRT $\approx 1 \mathrm{yr})$ fast cycling pool could resolve this discrepancy.

The observed increase in starch age with decreasing starch concentrations is consistent with a 'last in, first out' hypothesis of NSC dynamics. For example, Lacointe et al. (1993) proposed that the most recently added starch molecules are the first to be converted back to sugars to support metabolic demands. One interpretation of our result is that stressed trees (owing to climate, age, disease, damage, etc.) have greater demands for stored NSC because newer, younger photosynthetic products are not readily available. Thus, stressed trees are unable to replenish starch reserves with new sugar inputs but instead progressively draw down the youngest starch, which causes the remaining starch to become older as concentrations decline. Our two-pool model structure is consistent with this view, in that the younger fast cycling pool is used to support growth and metabolism. However, we know very little about some of the physiological details. For example, what is the age distribution - rather than just the mean age - of starch and sugars? How available are older stored reserves to the tree? Are there separate 'fast' and 'slow' components to both starch and sugars? How much mixing is there (e.g. across rings) of reserves after they have been deposited in ray parenchyma cells? (We note that incomplete mixing - i.e. older reserves in older rings - could explain the observation of correlations between the age of sugar and starch in each core, and the number of rings in the core.) At the present time, we do not have the field data necessary to parameterize a more complex model of NSC reserves in trees.

\section{Modeling of NSC pool dynamics}

A better understanding of $\mathrm{C}$ allocation and storage processes is needed to improve current-generation $\mathrm{C}$ cycling models (Trumbore, 2006). At the ecosystem scale and larger, models tend to ignore NSCs altogether (e.g. 'no-pool' models, such as SIPNET, Braswell etal., 2005; and DALEC, Williams etal., 2005) or adopt simple one-pool (e.g. PnET-II, Aber et al., 1995) representations. Even among models of individual tree growth, many do not explicitly model NSCs: Le Roux et al. (2001) surveyed 27 different models of this type and found that only five of these included a NSC reserve pool that was treated separately from a general dry matter pool. Regardless of the type of model considered, there have been few attempts to validate the dynamics of the modeled NSC pools against field measurements (Le Roux etal., 2001). Three notable exceptions are Cropper \& Gholz (1993), Sampson et al. (2001) and Gough etal. (2009). However, this is the first study to use direct ${ }^{14} \mathrm{C}$ measurements of stemwood NSC age to evaluate or constrain the MRT of modeled NSC reserves in an ecosystem model (cf. Gaudinski et al., 2009).

Our one-pool representation of NSC reserves required an unrealistically large pool in order to yield a MRT that matched with ${ }^{14} \mathrm{C}$-NSC data. Our two-pool structure (see also Chantuma et al., 2009; Kuptz etal., 2011; cf. Sampson et al., 2001; Ogee et al., 2009) offered both greater realism and better model performance, and seasonal patterns that are consistent with what has been previously reported (Kozlowski, 1992; Würth etal., 2005; Gough etal., 2009). The two-pool model, which pairs a young and dynamic 'fast' pool with an older and (mostly) static 'slow' pool, shows how the mean age of the total NSC pool can be decadal in scale while metabolism and growth are both preferentially supported by newer photosynthates (i.e. woody biomass increment lags carbon uptake by just 1 yr). Our model allows, however, for the slow pool to be drawn on if the fast pool is sufficiently depleted. If this were to occur, new growth or respired $\mathrm{CO}_{2}$ would be supported by much older stored NSCs from the slow pool. With the twopool approach, the model could be parameterized with reasonable values for both total pool size and MRT, and interannual variation in allocation to woody biomass increment more closely matched the observations. This improved performance, and greater realism, was achieved without requiring a substantial increase in model complexity. From the perspective of modeling forest responses to climate change, we expect that by incorporating a reserve pool into the model, the model system should be better able to represent the lagged effects of climate extremes and disturbance on ecosystem C fluxes.

\section{Conclusions}

We have conducted a unique 3-yr study to quantify the seasonal and interannual variability in NSC reserves for the dominant forest tree species of the northeastern United States. Our field data show that stemwood NSCs are highly dynamic on seasonal timescales and surprisingly old, ranging from several years to more than a decade in mean age. Modeling analyses showed that a two-pool representation of NSC reserves could match the measured age of stemwood NSCs, and greatly improved agreement between measured and modeled woody biomass increment, but highlighted uncertainties regarding the representativeness of the stemwood concentration measurements with respect to wholetree or ecosystem-scale carbohydrate budgets.

Construction of accurate NSC budgets requires careful sampling to measure NSC concentrations in roots, branches and foliage, in addition to stemwood, and then upscaling the concentration measurements to whole-tree quantities (e.g. Würth et al., 2005). The results shown here demonstrate how ${ }^{14} \mathrm{C}$-based estimates of NSC age can complement the concentration measurements and provide a constraint on MRT, which, from a modeling perspective, is important for getting the pool dynamics correct. It should also be possible, with a detailed measurement program, to use ${ }^{14} \mathrm{C}-\mathrm{NSC}$ as a tracer to distinguish older carbohydrate reserves from more recent photosynthetic products, which will provide additional insight into allocation and translocation processes.

Our analysis provides new insights into the dynamics and turnover of carbohydrate reserves in forest trees, but also challenges our understanding of allocation and storage processes, particularly at the whole-tree level. Future progress in this area should contribute to our ability to address questions about the availability of reserves to support growth and metabolism (e.g. 
carbon limitation vs sink limitation of growth, carbon starvation), not to mention the ecological and evolutionary role of active vs passive storage (Wiley and Helliker 2012).

\section{Acknowledgements}

This work was supported by the Office of Science (BER), US Department of Energy, through the Northeastern Regional Center of the National Institute for Climatic Change Research and under Interagency Agreement DE-SC0005578. A.D.R. acknowledges support from the Milton Fund at Harvard University. M.S.C. was supported by the NOAA Climate \& Global Change Postdoctoral Fellowship Program administered by UCAR, the Kearney Foundation of Soil Science and the National Center for Ecological Analysis and Synthesis, a Center funded by NSF (Grant \#EF-0553768). We thank Bob Evans, Bryan Dail, Will Young, Nick Huntington, and Chris Hansen for their assistance in the field and lab.

\section{References}

Aber JD, Ollinger SV, Federer CA, Reich PB, Goulden ML, Kicklighter DW, Melillo JM, Lathrop RG. 1995. Predicting the effects of climate change on water yield and forest production in the northeastern United States. Climate Research 5: 207-222.

Arneth A, Kelliher FM, McSeveny TM, Byers JN. 1998. Net ecosystem productivity, net primary productivity and ecosystem carbon sequestration in a Pinus radiata plantation subject to soil water deficit. Tree Physiology 18: 785-793.

Barbaroux C, Breda N. 2002. Contrasting distribution and seasonal dynamics of carbohydrate reserves in stem wood of adult ring-porous sessile oak and diffuseporous beech trees. Tree Physiology 22: 1201-1210.

Bond WJ, Midgley JJ. 2001. Ecology of sprouting in woody plants: the persistence niche. Trends in Ecology \& Evolution 16: 45-51.

Braswell BH, Sacks WJ, Linder E, Schimel DS. 2005. Estimating diurnal to annual ecosystem parameters by synthesis of a carbon flux model with eddy covariance net ecosystem exchange observations. Global Change Biology 11: 335-355.

Carbone MS, Czimczik CI, McDuffee KE, Trumbore SE. 2007. Allocation and residence time of photosynthetic products in a boreal forest using a low-level 14C pulse-chase labeling technique. Global Change Biology 13: 466-477.

Carbone MS, Still CJ, Ambrose AR, Dawson TE, Williams AP, Boot CM, Schaeffer SM, Schimel JP. 2011. Seasonal and episodic moisture controls on plant and microbial contributions to soil respiration. Oecologia 167: 265-278.

Carbone MS, Trumbore SE. 2007. Contribution of new photosynthetic assimilates to respiration by perennial grasses and shrubs: residence times and allocation patterns. New Phytologist 176: 124-135.

Chantuma P, Lacointe A, Kasemsap P, Thanisawanyangkura S, Gohet E, Clement A, Guilliot A, Ameglio T, Thaler P. 2009. Carbohydrate storage in wood and bark of rubber trees submitted to different level of $\mathrm{C}$ demand induced by latex tapping. Tree Physiology 29: 1021-1031.

Chapin FS, Schulze ED, Mooney HA. 1990. The ecology and economics of storage in plants. Annual Review of Ecology and Systematics 21: 423-447.

Cisneros-Dozal LM, Trumbore S, Hanson PJ. 2006. Partitioning sources of soilrespired $\mathrm{CO}_{2}$ and their seasonal variation using a unique radiocarbon tracer. Global Change Biology 12: 194-204.

Cook ER, Kairiukstis LA, eds. 1990. Methods of dendrochronology: applications in the environmental sciences. Dordrecht, the Netherlands: Kluwer Academic Publishers.

Cropper WP, Gholz HL. 1993. Simulation of the carbon dynamics of a Florida slash pine plantation. Ecological Modelling 66: 231-249.
Czimczik CI, Trumbore SE, Carbone MS, Winston GC. 2006. Changing sources of soil respiration with time since fire in a boreal forest. Global Change Biology 12: 957-971.

Dunn JP, Potter DA, Kimmerer TW. 1990. Carbohydrate reserves, radial growth and mechanisms of resistance of oak trees to phloem-boring insects. Oecologia 83: 458-468.

Fox A, Williams M, Richardson AD, Cameron D, Gove JH, Quaife T, Ricciuto $\mathrm{D}$, Reichstein M, Tomelleri E, Trudinger C et al. 2009. The REFLEX project: comparing different algorithms and implementations for the inversion of a terrestrial ecosystem model against eddy covariance data. Agricultural and Forest Meteorology 149: 1597-1615.

Friedlingstein P, Joel G, Field CB, Fung IY. 1999. Toward an allocation scheme for global terrestrial carbon models. Global Change Biology 5: 755-770.

Gaudillere JP, Moing A, Carbonne F. 1992. Vigor and nonstructural carbohydrates in young prune trees. Scientia Horticulturae 51: 197-211.

Gaudinski JB, Torn MS, Riley WJ, Swanston C, Trumbore SE, Joslin JD, Majdi H, Dawson TE, Hanson PJ. 2009. Use of stored carbon reserves in growth of temperate tree roots and leaf buds: analyses using radiocarbon measurements and modeling. Global Change Biology 15: 992-1014.

Gaudinski JB, Trumbore SE, Davidson EA, Cook AC, Markewitz D, Richter DD. 2001. The age of fine-root carbon in three forests of the eastern United States measured by radiocarbon. Oecologia 129: 420-429.

Gholz HL, Cropper WP. 1991. Carbohydrate dynamics in mature Pinus elliotti var elliotti trees. Canadian Journal of Forest Research 21: 1742-1747.

Gleason SM, Ares A. 2004. Photosynthesis, carbohydrate storage and survival of a native and an introduced tree species in relation to light and defoliation. Tree Physiology 24: 1087-1097.

Gough CM, Flower CE, Vogel CS, Dragoni D, Curtis PS. 2009. Wholeecosystem labile carbon production in a north temperate deciduous forest. Agricultural and Forest Meteorology 149: 1531-1540.

Grulke NE, Andersen CP, Hogsett WE. 2001. Seasonal changes in above- and belowground carbohydrate concentrations of ponderosa pine along a pollution gradient. Tree Physiology 21: 173-181.

Hoch G, Richter A, Korner C. 2003. Non-structural carbon compounds in temperate forest trees. Plant Cell \& Environment 26: 1067-1081.

Hollinger DY, Aber J, Dail B, Davidson EA, Goltz SM, Hughes H, Leclerc MY, Lee JT, Richardson AD, Rodrigues C et al. 2004. Spatial and temporal variability in forest-atmosphere $\mathrm{CO}_{2}$ exchange. Global Change Biology 10: 1689-1706.

Holmes RL. 1983. Computer assisted quality control in tree-ring dating and measurement. Tree Ring Bulletin 43: 69-78.

Hsueh DY, Krakauer NY, Randerson JT, Xu XM, Trumbore SE, Southon JR. 2007. Regional patterns of radiocarbon and fossil fuel-derived $\mathrm{CO}_{2}$ in surface air across North America. Geophysical Research Letters 34: Art. No. L02816.

Jenkins JP, Richardson AD, Braswell BH, Ollinger SV, Hollinger DY, Smith ML. 2007. Refining light-use efficiency calculations for a deciduous forest canopy using simultaneous tower-based carbon flux and radiometric measurements. Agricultural and Forest Meteorology 143: 64-79.

Kagawa A, Sugimoto A, Maximov TC. 2006a. ${ }^{13} \mathrm{CO}_{2}$ pulse-labelling of photoassimilates reveals carbon allocation within and between tree rings. Plant, Cell \& Environment 29: 1571-1584.

Kagawa A, Sugimoto A, Maximov TC. 2006b. Seasonal course of translocation, storage and remobilization of ${ }^{13} \mathrm{C}$ pulse-labeled photoassimilate in naturally growing Larix gmelinii saplings. New Phytologist 171: 793-804.

Keel SG, Siegwolf RTW, Jaggi M, Korner C. 2007. Rapid mixing between old and new $\mathrm{C}$ pools in the canopy of mature forest trees. Plant, Cell $\approx$ Environment 30: 963-972.

Keel SG, Siegwolf RTW, Korner C. 2006. Canopy $\mathrm{CO}_{2}$ enrichment permits tracing the fate of recently assimilated carbon in a mature deciduous forest. New Phytologist 172: 319-329.

Keenan TF, Carbone MS, Reichstein M, Richardson AD. 2011. The model-data fusion pitfall: assuming certainty in an uncertain world. Oecologia 167: 587597.

Keenan TF, Davidson E, Moffat A, Munger W, Richardson AD. 2012. Using model-data fusion to interpret past trends, and quantify uncertainties in future projections, of terrestrial ecosystem carbon cycling. Global Change Biology 18: 2555-2569. 
Körner C. 2003. Carbon limitation in trees. Journal of Ecology 91: 4-17.

Kozlowski TT. 1992. Carbohydrate sources and sinks in woody plants. Botanical Review 58: 107-222.

Kuptz D, Fleischmann F, Matyssek R, Grams TEE. 2011. Seasonal patterns of carbon allocation to respiratory pools in 60-yr-old deciduous (Fagus sylvatica) and evergreen (Picea abies) trees assessed via whole-tree stable carbon isotope labeling. New Phytologist 191: 160-172.

Lacointe A, Kajji A, Daudet FA, Archer P, Frossard JS. 1993. Mobilization of carbon reserves in young walnut trees. Acta Botanica Gallica 140: 435-441.

Le Roux X, Lacointe A, Escobar-Gutierrez A, Le Dizes S. 2001. Carbon-based models of individual tree growth: a critical appraisal. Annals of Forest Science 58 : 469-506.

Leavitt SW, Danzer SR. 1993. Method for batch processing small wood samples to holocellulose for stable carbon isotope analysis. Analytical Chemistry 65: 87-89.

Levin I, Hammer S, Kromer B, Meinhardt F. 2008. Radiocarbon observations in atmospheric $\mathrm{CO}_{2}$ : determining fossil fuel $\mathrm{CO}_{2}$ over Europe using Jungfraujoch observations as background. Science of the Total Environment 391: 211-216.

Levin I, Kromer B. 2004. The tropospheric ${ }^{14} \mathrm{CO}_{2}$ level in mid-latitudes of the Northern Hemisphere (1959-2003). Radiocarbon 46: 1261-1272.

Levin I, Naegler T, Kromer B, Diehl M, Francey RJ, Gomez-Pelaez AJ, Steele LP, Wagenbach D, Weller R, Worthy DE. 2010. Observations and modelling of the global distribution and long-term trend of atmospheric ${ }^{14} \mathrm{CO}_{2}$. Tellus Series B-Chemical and Physical Meteorology 62: 26-46.

Millers I, Lachance D, Burkman WG, Allen DC. 1991 North American Sugar Maple Decline Project: organization and field methods (GTR NE-154). Radnor, PA, USA: US Department of Agriculture Forest Service, Northeastern Forest Experiment Station.

Navarro MNV, Jourdan C, Sileye T, Braconnier S, Mialet-Serra I, Saint-Andre L, Dauzat J, Nouvellon Y, Epron D, Bonnefond JM et al. 2008. Fruit development, not GPP, drives seasonal variation in NPP in a tropical palm plantation. Tree Physiology 28: 1661-1674.

Ogee J, Barbour MM, Wingate L, Bert D, Bosc A, Stievenard M, Lambrot C, Pierre M, Bariac T, Loustau D et al. 2009. A single-substrate model to interpret intra-annual stable isotope signals in tree-ring cellulose. Plant, Cell $\sigma$ Environment 32: 1071-1090.

Reimer PJ, Brown TA, Reimer RW. 2004. Discussion: reporting and calibration of post-bomb ${ }^{14} \mathrm{C}$ data. Radiocarbon 46: 1299-1304.

Richardson AD, Williams M, Hollinger DY, Moore DJP, Dail DB, Davidson EA, Scott NA, Evans RS, Hughes H, Lee JT et al. 2010. Estimating parameters of a forest ecosystem $\mathrm{C}$ model with measurements of stocks and fluxes as joint constraints. Oecologia 164: 25-40.

Rocha AV, Goulden ML. 2009. Why is marsh productivity so high? New insights from eddy covariance and biomass measurements in a Typha marsh. Agricultural and Forest Meteorology 149: 159-168.

Rocha AV, Goulden ML, Dunn AL, Wofsy SC. 2006. On linking interannual tree ring variability with observations of whole-forest $\mathrm{CO}_{2}$ flux. Global Change Biology 12: 1378-1389.

Sampson DA, Johnsen KH, Ludovici KH, Albaugh TJ, Maier CA. 2001. Standscale correspondence in empirical and simulated labile carbohydrates in loblolly pine. Forest Science 47: 60-68.

Schuur EAG, Trumbore SE. 2006. Partitioning sources of soil respiration in boreal black spruce forest using radiocarbon. Global Change Biology 12: $165-176$

Southon J, Santos G, Druffel-Rodriguez K, Druffel E, Trumbore S, Xu XM, Griffin S, Ali S, Mazon M. 2004. The Keck Carbon Cycle AMS laboratory, University of California, Irvine: initial operation and a background surprise. Radiocarbon 46: 41-49.

Stokes MA, Smiley TL. 1968. An introduction to tree-ring dating. Chicago, IL, USA: University of Chicago Press.

Thornley JHM, Cannell MGR. 2000. Modelling the components of plant respiration: representation and realism. Annals of Botany 85: 55-67.

Trumbore S. 2006. Carbon respired by terrestrial ecosystems - recent progress and challenges. Global Change Biology 12: 141-153.
Urbanski S, Barford C, Wofsy S, Kucharik C, Pyle E, Budney J, McKain K, Fitzjarrald D, Czikowsky M, Munger JW. 2007. Factors controlling $\mathrm{CO}_{2}$ exchange on timescales from hourly to decadal at Harvard Forest. Journal of Geophysical Research-Biogeosciences 112: Art. No. G02020.

Vargas R, Trumbore SE, Allen MF. 2009. Evidence of old carbon used to grow new fine roots in a tropical forest. New Phytologist 182: 710-718.

Wargo PM, Minocha R, Wong BL, Long RP, Horsley SB, Hall TJ. 2002. Measuring changes in stress and vitality indicators in limed sugar maple on the Allegheny Plateau in north-central Pennsylvania. Canadian Journal of Forest Research 32: 629-641.

Wiley E, Helliker B. 2012. A re-evaluation of carbon storage in trees lends greater support for carbon limitation to growth. New Phytologist 195: 285-289.

Williams M, Schwarz PA, Law BE, Irvine J, Kurpius MR. 2005. An improved analysis of forest carbon dynamics using data assimilation. Global Change Biology 11: 89-105.

Wong BL, Baggett KL, Rye AH. 2003. Seasonal patterns of reserve and soluble carbohydrates in mature sugar maple (Acer saccharum). Canadian Journal of Botany 81: 780-788.

Würth MKR, Pelaez-Riedl S, Wright SJ, Korner C. 2005. Non-structural carbohydrate pools in a tropical forest. Oecologia 143: 11-24.

Xu X, Trumbore SE, Zheng S, Southon JR, McDuffee KE, Luttgen M, Liu JC. 2007. Modifying a sealed tube zinc reduction method for preparation of AMS graphite targets: reducing background and attaining high precision. Nuclear Instruments \& Methods in Physics Research Section B-Beam Interactions with Materials and Atoms 259: 320-329.

\section{Supporting Information}

Additional supporting information may be found in the online version of this article.

Fig. S1 Climatic anomalies 2007-2010.

Fig. S2 Yields of sugar extractions (mg C per $2 \mathrm{~cm}$ core) using two different methods.

Fig. S3 Composition of total nonstructural carbohydrate (NSC) pool.

Fig. S4 Differences in mean stemwood concentrations of nonstructural carbohydrates between 'dead' and 'healthy' paper birch trees at Bartlett Experimental Forest.

Table S1 Seasonal variability in nonstructural carbohydrates (NSCs).

Notes S1 Comparison of sugar yields from two different extractions.

Notes S2 Nonstructural carbohydrate (NSC) dynamics in declining and dead trees.

Please note: Wiley-Blackwell are not responsible for the content or functionality of any supporting information supplied by the authors. Any queries (other than missing material) should be directed to the New Phytologist Central Office. 


\section{Supporting Information Figs S1-S4, Table S1 and Notes S1 \& S2}

Fig. S1 Climatic anomalies 2007-2010. Monthly and annual anomalies (in standard deviations from the 2001-2010 mean) for air temperature, solar radiation, and precipitation for the three study sites. The extremely warm spring of 2010 is the most notable, and consistent, feature. Vertical lines denote January 1.
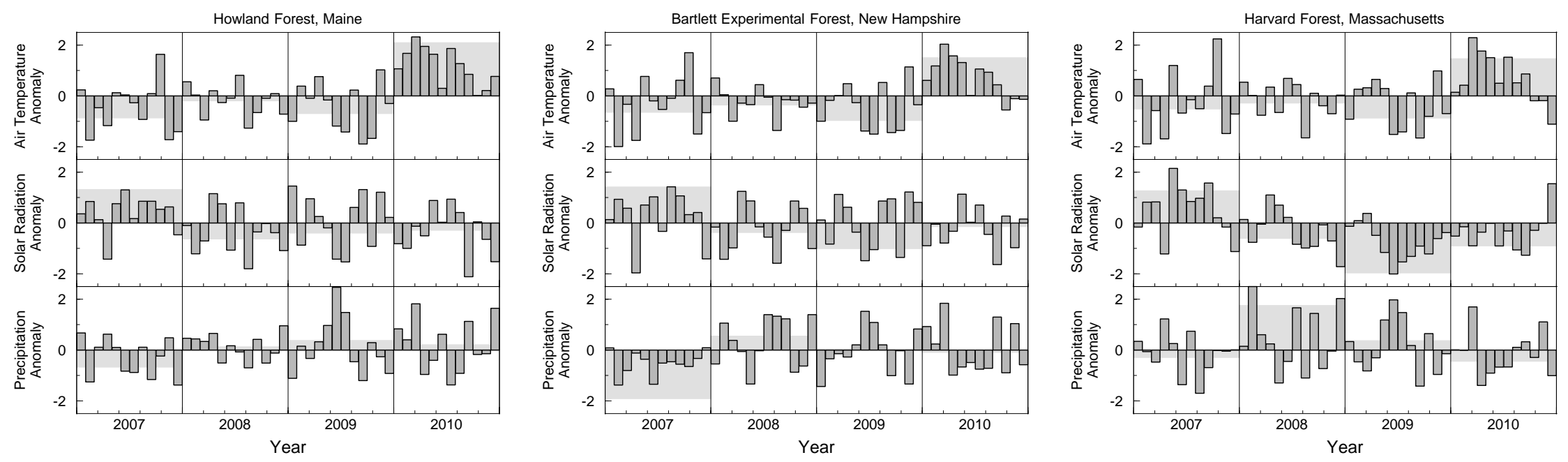


\section{Notes S1 Comparison of sugar yields from two different extractions.}

Here we compare the yields of sugar extractions following methods of Wong et al. (2003), conducted using methods of C. Czimczik et al. (unpublished) ( $y$-axis; conducted by Czimczik and Xu at UC Irvine) and Wong et al. (2003) ( $x$-axis, conducted by Schaberg and Murakami at USDA Forest Service). We note that separate cores were used for each analysis (i.e. samples were not homogenized).

The dotted line shows the 1:1 line, and the solid line is the reduced major axis (RMA) regression line, calculated using a Java applet available online (http://www.bio.sdsu.edu/pub/andy/rma.html). RMA regression is preferred over ordinary least squares (OLS) as both $x$ and $y$ values are measured with error (OLS assumes no error in $\mathrm{x}$ values; biased slope estimates result when this assumption is violated). Based on jackknife estimates, the RMA line has an intercept of 0.69 (SE = $0.25)$ and slope of $0.63(\mathrm{SE}=0.16)$. For comparative purposes, the standard OLS regression lines ( $x$ vs $y$ and $y$ vs $x$ ) are shown as dotted red lines.

RMS error statistics, calculated as sqrt(sum(predicted - actual) $)^{2}$ ) in both the $x$ and $y$ directions, are as follows:

\begin{tabular}{lcc} 
& Czimczik et al. & Wong et al. \\
\hline RMA Regression & 0.26 & 0.43 \\
OLS (y: Czimczik et al.) & 0.24 & 0.54 \\
OLS (y: Wong et al. $)$ & 0.40 & 0.32 \\
1:1 Line & 0.41 & 0.41
\end{tabular}

Fig. S2 Yields of sugar extractions (mg C per $2 \mathrm{~cm}$ core) using two different methods.

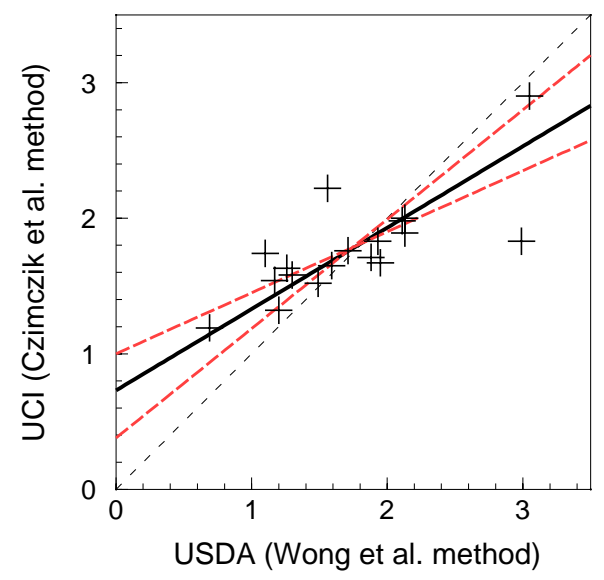


Fig. S3 Composition of total NSC pool. Variation across species in the composition of stemwood nonstructural carbohydrates (NSCs), measured in mg of NSC per gram of oven-dry (OD) wood. Means were calculated first across all sampling dates for each tree, then across $n=20$ trees for each species at each site. Raffinose and stachyose are lumped as 'other'. Error bars denote \pm 1 SD of the mean for total NSCs.
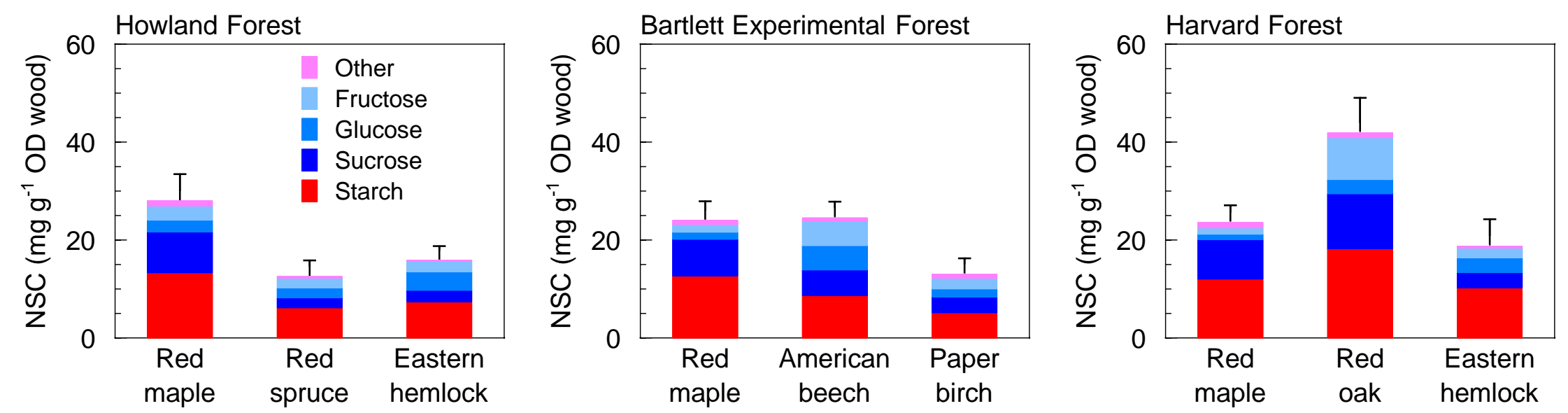


\section{Notes S2 NSC dynamics in declining and dead trees.}

Four of the 20 paper birch tagged and cored at Bartlett died over the course of the study. An additional two trees were classified as in severe decline at the end of the 2010 growing season. Starch concentrations and dynamics (lower in dormant season, higher in growing season) were similar in both dead and healthy trees through our final sampling (Fig. S4, top). However, in the dead trees, pronounced declines in stemwood sugar reserves were observed as early as November 2008, at which time the concentration of sugars in two of the four trees dropped to $<1 \mathrm{mg} \mathrm{g}^{-1}$. By 2010 , dormant and growing season sugar concentrations were near zero in all dead trees (Fig. S4, bottom).

The observed mortality does not appear to be related to specific recent events but rather to a gradual decline in health. Ring width measurements suggest that growth rates of paper birch at Bartlett were negatively impacted by an ice storm that occurred in the winter of 1998. In the three years before the ice storm, healthy and dead or severe decline trees had similar rates of basal area increment (BAI), $5.6 \pm 2.9$ and $4.5 \pm 3.8 \mathrm{~cm}^{2} \mathrm{yr}^{-1}$, respectively. However, trees rated healthy showed no significant trend in BAI over the last decade $(r=-0.05, P=0.89)$ whereas dead and severe decline trees showed a steady decrease in BAI $(r=-0.90, P<0.001)$ over the same period. Over the last five years, healthy trees had a mean BAI of $3.8 \pm 1.8 \mathrm{~cm}^{2} \mathrm{yr}^{-1}$, compared with $0.3 \pm 0.2 \mathrm{~cm}^{2} \mathrm{yr}^{-1}$ in dead or severe decline trees. During this time, mean BAI of red maple $\left(8.6 \pm 5.5 \mathrm{~cm}^{2} \mathrm{yr}^{-1}\right)$ and American beech $\left(5.5 \pm 2.8 \mathrm{~cm}^{2} \mathrm{yr}^{-1}\right)$ was substantially higher than that of even the 'healthy' birch, and showed no significant time trends $(r=0.55, P=0.09$, and $r=0.15, P$ $=0.68$, respectively).

Fig. S4 Differences in mean stemwood concentrations of nonstructural carbohydrates (starch and sugars) between 'dead' $(n=4)$ and 'healthy' $(n=7)$ paper birch trees at Bartlett Experimental Forest. Data are means for dormant season (November, March collections) and growing season (June, August) collections, but note that not all trees were sampled at each collection date. Error bars denote \pm 1 SD of the mean.

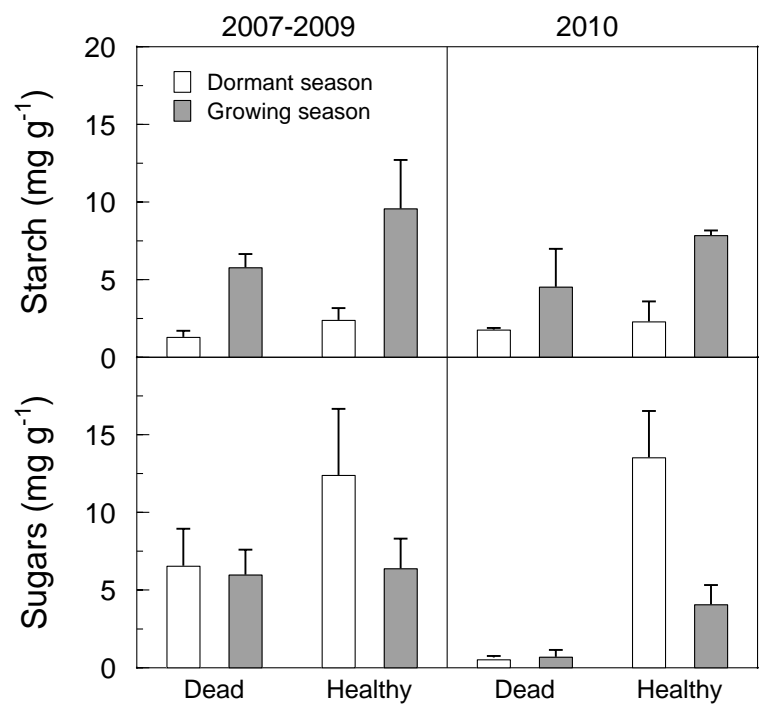


Table S1 Seasonal variability in NSCs. Statistical significance of seasonal variability in stemwood starch, sugar, and total NSC concentrations, by species and study site. Seasonal variability quantified using single-factor analysis of variance, with sampling month (June, August, November, March) as class variable (left columns), or first-order Fourier regression with phase and amplitude as fit parameters (right columns). The results were consistent across both approaches. $R^{2}$ is the proportion of total variance explained by the model, and $P$-value is the level of statistical significance, based on an $F$-test; bold type denotes results significant at $P \leq 0.05$. Overall, $n=12$ independent samples per species per site ( 4 sampling dates per year, over $3 \mathrm{yr}$; at each sampling date, the value for a species represents the mean across 10 individual trees).

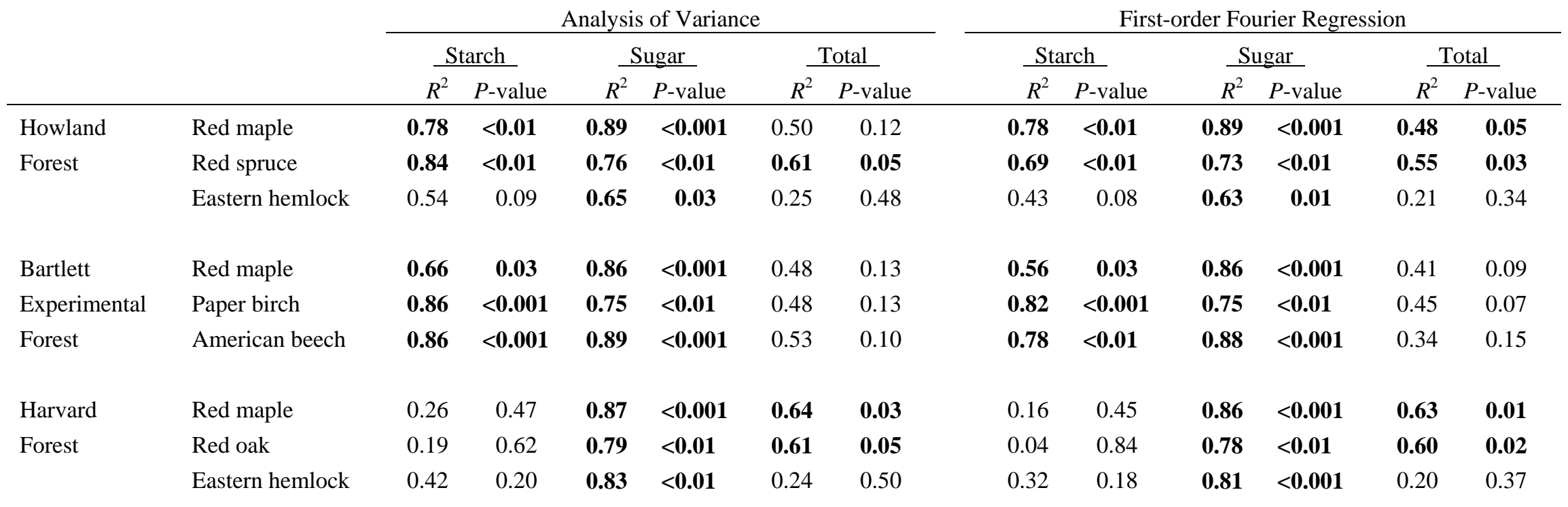

